AperTO - Archivio Istituzionale Open Access dell'Università di Torino

\title{
Exposure of neuroblastoma cell lines to imatinib results in the upregulation of the CDK inhibitor p27KIP1 as a consequence of c-Abl inhibition
}

\section{This is the author's manuscript}

Original Citation:

Availability:

This version is available http://hdl.handle.net/2318/155483

since 2016-01-18T10:59:37Z

Published version:

DOI:10.1016/j.bcp.2014.09.016

Terms of use:

Open Access

Anyone can freely access the full text of works made available as "Open Access". Works made available under a Creative Commons license can be used according to the terms and conditions of said license. Use of all other works requires consent of the right holder (author or publisher) if not exempted from copyright protection by the applicable law. 


\title{
Exposure of neuroblastoma cell lines to imatinib results in the upregulation of the CDK inhibitor $\mathrm{p} 27^{\mathrm{KIP} 1}$ as a consequence of c-Abl inhibition
}

\author{
Elisa Lupino, Cristina Ramondetti, Barbara Buccinnà, Marco Piccinini * \\ Department of Oncology, School of Medicine, University of Torino, Italy
}

\section{A R T I C L E I N F O}

\section{Article history:}

Received 25 July 2014

Accepted 19 September 2014

Available online 26 September 2014

Chemical compounds studied in this article: Imatinib (PubChem CID: 123596)

Cycloheximide (PubChem CID: 6197)

5-bromo-2'-deoxyuridine (PubChem CID:

6035)

Hoechst 33258 (PubChem CID: 16218619)

\section{Keywords:}

Imatinib

Neuroblastoma

p2 $7^{\text {KIP1 }}$

c-Abl

CDK2

$\mathrm{pRb}$

\begin{abstract}
A B S T R A C T
Imatinib mesylate is a tyrosine kinase inhibitor with selectivity for abelson tyrosine-protein kinase 1 (c-Abl), breakpoint cluster region (Bcr)-Abl fusion protein (Bcr-Abl), mast/stem cell growth factor receptor Kit (c-Kit), and platelet-derived growth factor receptor (PDGFR). Previous studies demonstrated that imatinib in the low micromolar range exerted antiproliferative effects on neuroblastoma cell lines. However, although neuroblastoma cells express c-Kit and PDGFR, the imatinib concentrations required to achieve significant growth inhibitory effects $(\geq 10 \mu \mathrm{M})$ are substantially higher than those required for inhibition of ligand-induced phosphorylation of wild type c-Kit and PDGFR ( $\leq 1 \mu \mathrm{M})$, suggesting that additional mechanisms are responsible for the antitumor activity of imatinib on these cells. In this study, we show that treatment of neuroblastoma cell lines with 1-15 $\mu \mathrm{M}$ imatinib resulted in a dose dependent inhibition of 5-bromo-2'-deoxyuridine (BrdU) incorporation into newly synthesized DNA. The antiproliferative effect of imatinib was dependent on the upregulation of the cyclin-dependent kinase $(\mathrm{CDK})$ inhibitor $\mathrm{p} 27^{\mathrm{KIP} 1}$ in the nuclear compartment as a result of increased $\mathrm{p} 27^{\mathrm{KIP} 1}$ protein stability. We demonstrate that the mechanism of $\mathrm{p} 27^{\mathrm{KIP} 1}$ stabilization relied on inhibition of $\mathrm{p} 27^{\mathrm{KIP} 1}$ phosphorylation on tyrosine residues by c-Abl. We provide evidence that in neuroblastoma cell lines a significant fraction of cellular c-Abl is phosphorylated on Tyr-245, consistent with an open and active conformation. Notably, exposure to imatinib did not affect Tyr-245 phosphorylation. Given the low affinity of active c-Abl for imatinib, these data provide a molecular explanation for the relatively high imatinib concentrations required to inhibit neuroblastoma cell proliferation.
\end{abstract}

(c) 2014 Elsevier Inc. All rights reserved.

\section{Introduction}

The CDK inhibitor $\mathrm{p} 27^{\mathrm{KIP} 1}$ is a key regulator of $\mathrm{G} 1$ to $\mathrm{S}$ phase transition in eukaryotic cells. In normal cells during G0 and early $\mathrm{G} 1$ phase high levels of $\mathrm{p} 27^{\mathrm{KIP} 1}$ bind to and inhibit the activity of

\footnotetext{
Abbreviations: CDK, cyclin-dependent kinase; c-Abl, abelson tyrosine-protein kinase 1; Bcr-Abl, breakpoint cluster region (Bcr)-Abl fusion protein; c-Kit, mast/ stem cell growth factor receptor Kit; PDGFR, platelet-derived growth factor receptor; SKP2, S-phase kinase-associated protein 2; HRP, horseradish peroxidase; $\mathrm{pRb}$, retinoblastoma protein; PARP, poly-(ADP-ribose)-polymerase; siRNA, short interfering RNA; CHX, cycloheximide; BrdU, 5-bromo-2'-deoxyuridine; df, degree of freedom.

* Corresponding author at: Università di Torino, Dipartimento di Oncologia, via Michelangelo Buonarroti 27/B, 10126 Torino, Italy. Tel.: +39 0116705303; fax: +390116705310.

E-mail address: marco.piccinini@unito.it (M. Piccinini).
}

nuclear cyclin D-CDK4/6 and cyclin E-CDK2 complexes. During G1 to $S$ phase transition, $\mathrm{p} 27^{\mathrm{KIP} 1}$ abundance decreases, mainly because of enhanced degradation, allowing the activation of cyclin-CDK complexes to support S-phase entry $[1,2]$. The instability of p $27^{\mathrm{KIP} 1}$ in late G1 is triggered by cyclin E-CDK2-dependent phosphorylation on Thr-187 which results in recruitment of $\mathrm{p} 27^{\mathrm{KIP} 1}$ to a S-phase kinase-associated protein 2 (SKP2)-containing ubiquitin ligase and degradation by the $26 \mathrm{~S}$ proteasome [3]. Reduced $\mathrm{p} 27^{\mathrm{KIP} 1}$ protein levels caused by accelerated proteolysis characterize many human cancers $[1,2]$.

Previous studies have demonstrated that tyrosine phosphorylation triggers the transition of $\mathrm{p} 27^{\mathrm{KIP} 1}$ from inhibitor to noninhibitor of cyclin-CDK complexes and converts p2 $7^{\mathrm{KIP} 1}$ into a substrate of cyclin E-CDK2 complexes [4,5]. Of the three tyrosine residues in $\mathrm{p} 27^{\mathrm{KIP} 1}$ (Tyr-74, Tyr-88, and Tyr-89), the two adjacent residues Tyr- 88 and Tyr- 89 are part of the inhibitory $3_{10}$ helix of 
$\mathrm{p} 27^{\mathrm{KIP} 1}$ which, by inserting into the catalytic cleft of CDK2, competes with ATP binding [6]. Upon tyrosine phosphorylation by Abl- or Src-family non-receptor tyrosine kinases, the inhibitory $3_{10}$ helix is ejected from the ATP-binding site of CDK2, partially restoring CDK2 activity. This event would allow cyclin E-CDK2 to phosphorylate Thr-187 leading to $\mathrm{p} 27^{\mathrm{KIP} 1}$ proteolytic degradation and complete CDK2 activation [4,5]. c-Abl is a $\approx 130 \mathrm{kDa}$ protein localized to the plasma membrane, cytosol and nucleus. The activity of c-Abl is tightly regulated. Inactive c-Abl is in a closed auto-inhibited conformation that involves several intra-molecular interactions. Upon phosphorylation by upstream signaling kinases or auto-phosphorylation events, c-Abl undergoes conformational changes resulting in extensive domain rearrangements and increased catalytic activity $[7,8]$. Tyr-412 and Tyr-245 are major sites of regulatory control in c-Abl. Phosphorylation on Tyr-245, by disrupting the intra-molecular engagement between the Src homology $(\mathrm{SH}) 3$ domain and the SH2-kinase linker domain of the auto-inhibited structure, stabilizes c-Abl in an open and active conformation [9]. The small molecule inhibitor imatinib (STI-571) specifically recognizes the inactive conformation of c-Abl. By binding with high affinity $\left(\mathrm{IC}_{50} \leq 0.2 \mu \mathrm{M}\right)$ to the ATP-binding pocket of non-phosphorylated c-Abl, imatinib prevents binding of ATP to the kinase domain, resulting in c-Abl inactivation. Transition into the active conformation greatly reduces the affinity of c-Abl for imatinib (IC $50 \approx 7 \mu \mathrm{M})[10,11]$.

Previous studies have demonstrated that imatinib, a tyrosine kinase inhibitor with selectivity for c-Abl, Bcr-Abl, c-Kit and PDGFR [12], exerts antiproliferative effects on neuroblastoma cell lines $[13,14]$. Although neuroblastoma cell lines express c-Kit and PDGFR, the imatinib concentrations required to achieve significant growth inhibitory effects $(\geq 10 \mu \mathrm{M})$ are substantially higher than those required for inhibition of ligand-induced phosphorylation of wild type c-Kit and PDGFR $(\leq 1 \mu \mathrm{M})$, suggesting that additional mechanisms are responsible for the antitumor activity of imatinib on these cells. In the present study the effects of imatinib on the expression of the CDK inhibitor $\mathrm{p} 27^{\mathrm{KIP} 1}$ were investigated in a panel of neuroblastoma cell lines.

\section{Materials and methods}

\subsection{Cell culture and drug treatments}

The N-myc proto-oncogene protein (MYCN) amplified IMR5 [15] and MYCN single copy SJ-N-KP [16], SK-N-AS [17], and SK-NF1 [17] cell lines were used throughout this study. IMR5, SK-N-AS, and SK-N-F1 cells have the wild-type and unamplified ALK gene $[18,19]$. IMR5 and SK-N-F1 are of N-type [20,21], SK-N-AS cells are of S-type [22]. IMR5, SK-N-AS, and SK-N-F1 cell lines were obtained in October 2012 from Banca Biologica e Cell Factory, IRCCS Azienda Ospedaliera Universitaria San Martino-IST Istituto Nazionale per la Ricerca sul Cancro (Genova, Italy). The SJ-N-KP cell line was a kind gift of Prof. Pession (Policlinico S. Orsola-Malpighi, Bologna, Italy) and was received from his laboratory in October 2012. Cells were passaged every 2-3 days and discarded after 8-10 passages. Cells were maintained in monolayer cultures at $37{ }^{\circ} \mathrm{C}$ in a $5 \% \mathrm{CO}_{2}$ humidified atmosphere. IMR5 and SJ-N-KP cells were cultured in Roswell Park Memorial Institute (RPMI-1640 medium) (R-8758, Sigma, Milan, Italy) whereas SK-N-AS and SK-N-F1 cells were cultured in Dulbecco's modified Eagle's medium (DMEM) (D-5796, Sigma, Milan, Italy). RPMI-1640 and DMEM were supplemented with $10 \%(v / v)$ fetal bovine serum (F-7524, Sigma, Milan, Italy) and $1 \%(\mathrm{v} / \mathrm{v})$ antibiotic-antimycotic solution (A-5955, Sigma, Milan, Italy) (complete medium). Imatinib mesylate (ALX-270-492) was from Alexis (Florence, Italy) and was solubilized in DMSO (drug vehicle, 41639 Fluka, Milan, Italy) at a final concentration of $10 \mathrm{mM}$, which was used as the stock solution for all experiments.
Final dilutions were made in culture medium. Exponentially growing neuroblastoma cells $\left(2 \times 10^{6}\right)$ cultured in complete medium in 6-well plates were exposed to imatinib at the indicated concentrations for $24 \mathrm{~h}$ (SJ-N-KP, IMR5, SK-N-F1) or $48 \mathrm{~h}$ (SK-NAS). For cycloheximide chase analysis neuroblastoma cells $\left(2 \times 10^{6}\right)$ cultured in complete medium in 6-well plates were exposed to $15 \mu \mathrm{M}$ imatinib for 24 or $48 \mathrm{~h}$, washed with fresh culture medium and then treated with $25 \mu \mathrm{g} / \mathrm{mL}$ cycloheximide (CHX) (C-4859, Sigma, Milan, Italy) added with DMSO or $15 \mu \mathrm{M}$ imatinib for further 4 or $8 \mathrm{~h} \mathrm{[23].} \mathrm{Whole} \mathrm{cell} \mathrm{extracts} \mathrm{were}$ prepared at 0,4 and $8 \mathrm{~h}$ and subjected to immunoblotting.

\subsection{BrdU incorporation assays}

The effects of imatinib on cell proliferation were tested using 5-bromo-2'-deoxyuridine (BrdU) incorporation assay (11669915001, Roche, Milan, Italy). Briefly, neuroblastoma cells $\left(2 \times 10^{4} /\right.$ well $)$ were plated in 96 well culture plates and cultured in complete medium. Increasing concentrations of imatinib were added for $24 \mathrm{~h}$ (SJ-N-KP, IMR5, SK-N-F1) or $48 \mathrm{~h}$ (SK-N-AS). BrdU label was added at a final concentration of $10 \mu \mathrm{M}$ for the last $16 \mathrm{~h}$. Cells were treated with fixative/denaturing solution and then incubated with anti-BrdU-peroxidase conjugate. BrdU incorporation was quantified according to the manufacturer's instructions using a GloMax luminometer (Promega, Milan, Italy). To evaluate the effects of $\mathrm{p} 27^{\mathrm{KIP} 1}$ gene silencing or expression of $\mathrm{p} 27^{\mathrm{Y} 88 \mathrm{~F} / \mathrm{Y} 89 \mathrm{~F}}$ or wild type (WT) p27 $7^{\mathrm{KIP} 1}$ on BrdU incorporation, cells transfected with p27 $7^{\mathrm{KIP} 1}$-targeting siRNA or a plasmid coding for $\mathrm{p} 27^{\mathrm{Y} 88 \mathrm{~F} / \mathrm{Y} 89 \mathrm{~F}}$ or WT p $27^{\mathrm{KIP} 1}$ were seeded into a 96 -well culture plate $\left(2 \times 10^{4}\right.$ cells/well) and cultured for $24 \mathrm{~h}$ in complete medium before addition of BrdU label at a final concentration of $10 \mu \mathrm{M}$ for $16 \mathrm{~h}$. BrdU incorporation was quantified as described above.

\subsection{Protein extraction, immunoblotting and immunoprecipitation}

Polyclonal antibodies to p27 ${ }^{\mathrm{KIP} 1}$ (sc-528), CDK4 (sc-260), CDK6 (sc-177), poly-(ADP-ribose)-polymerase (PARP) (sc-7150), cyclin E (sc-481), cyclin D1 (sc-753), monoclonal antibodies to CDK2 (sc6248), cyclin A (sc-56300), pan-phosphotyrosine (sc-7020), and horseradish peroxidise (HRP)-conjugated secondary antibodies were from Santa Cruz Biotechnology (Heidelberg, Germany). Polyclonal antibodies to c-Abl (2862), phospho-c-Abl tyrosine (Tyr)-245 (2868) and phospho-pRb serine (Ser)-780 (3590) were from Cell Signaling (Rome, Italy). Polyclonal antibody to phospho$\mathrm{pRb}$ threonine (Thr)-821 (9307) was from Biomol (Rome, Italy). Monoclonal antibody to $\beta$-actin (A-5441) was from Sigma (Milan, Italy). Monoclonal antibody to SKP2 (32-3300) and polyclonal antibody to phospho-p27 ${ }^{\mathrm{KIP} 1} \mathrm{Thr}-187$ (71-7700) were from Life Technologies (Milan, Italy). IMR5, SJ-N-KP, SK-N-AS, and SK-N-F1 cells were collected using a cell scraper, washed with PBS, counted manually, lysed with cell extraction buffer (FNN0011, Life Technologies, Milan, Italy) $\left(30 \mu \mathrm{L} / 1 \times 10^{6}\right.$ cells $)$ supplemented with $1 \%(\mathrm{v} / \mathrm{v})$ protease inhibitor mixture (P8340, Sigma, Milan, Italy) and 4\% (v/v) phosphatase inhibitor mixture (P-0044, Sigma, Milan, Italy) and centrifuged at $15,000 \times \mathrm{g}$ for $20 \mathrm{~min}$ at $4{ }^{\circ} \mathrm{C}$. Proteins were quantified using Protein Assay Kit II (500-0002, BioRad, Milan, Italy). Proteins ( $20 \mu \mathrm{g} /$ lane) were resolved by SDSpolyacrylamide gel electrophoresis (PAGE) on 9 or $12 \%$ gels and electro-transferred $(16 \mathrm{v}, 12 \mathrm{~h})$ at $4{ }^{\circ} \mathrm{C}$ to polyvinylidene fluoride membranes (PVDF) (IPVH00010, Millipore, Milan, Italy) equilibrated in Towbin buffer [24]. Membranes were blocked in 5\% (w/v) BSA (sc-2323, Santa Cruz Biotechnology, Heidelberg, Germany) in $20 \mathrm{mM}$ Tris pH 7.6, $140 \mathrm{mM} \mathrm{NaCl}, 0.02 \%$ (v/v) Tween-20 (blocking buffer) and probed with the indicated primary antibodies diluted in blocking buffer. The commercial antibodies were used at dilutions of $1: 500-1: 1000$, except for the anti- $\beta$-actin antibody 
employed at a dilution of 1:20,000. After washing, membranes were incubated with HRP-conjugated secondary antibodies diluted in blocking buffer. Immunoreactive bands were revealed by enhanced chemiluminscence (ECL) (Millipore, Milan, Italy) and visualized using G:Box Chemi-XT CCD gel-imaging system and GeneSnap image acquisition software (SynGene, Cambridge, UK). Immunoreactive bands were quantitated using GeneTool software
(SynGene, Cambridge, UK). Immunoprecipitation of $\mathrm{p} 27^{\mathrm{KIP} 1}$ or cAbl from whole cell extracts were carried-out using the indicated antibodies conjugated to Dynabeads protein-A (100.01D, Life Technologies, Milan, Italy) according to manufacturer's specifications. Dynabeads-IgG conjugates were combined with $100 \mu \mathrm{L}$ whole cell extract containing $500 \mu \mathrm{g}$ protein (DMSO treated cells or cells transfected with non-targeting control siRNA or empty
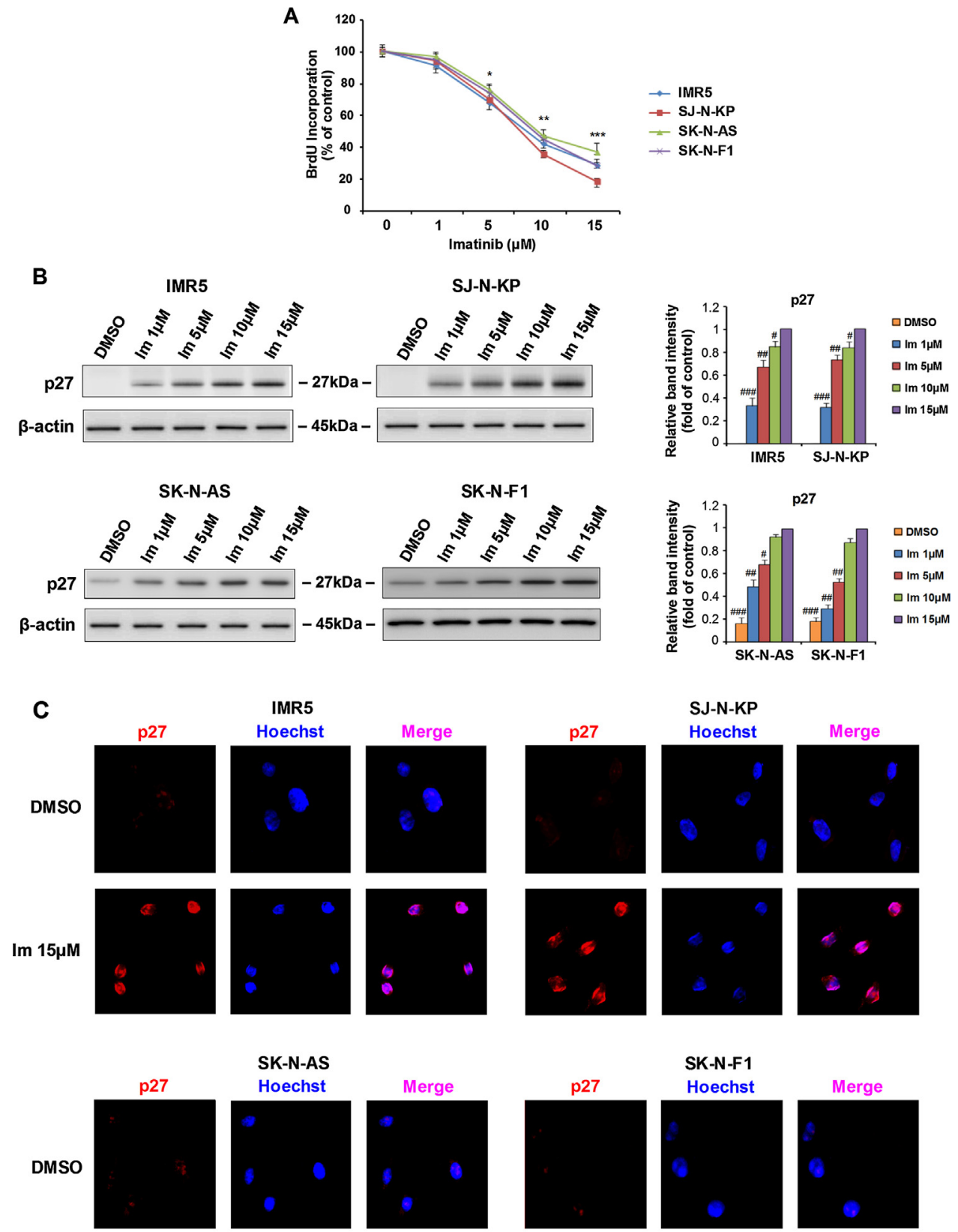

SK-N-F1
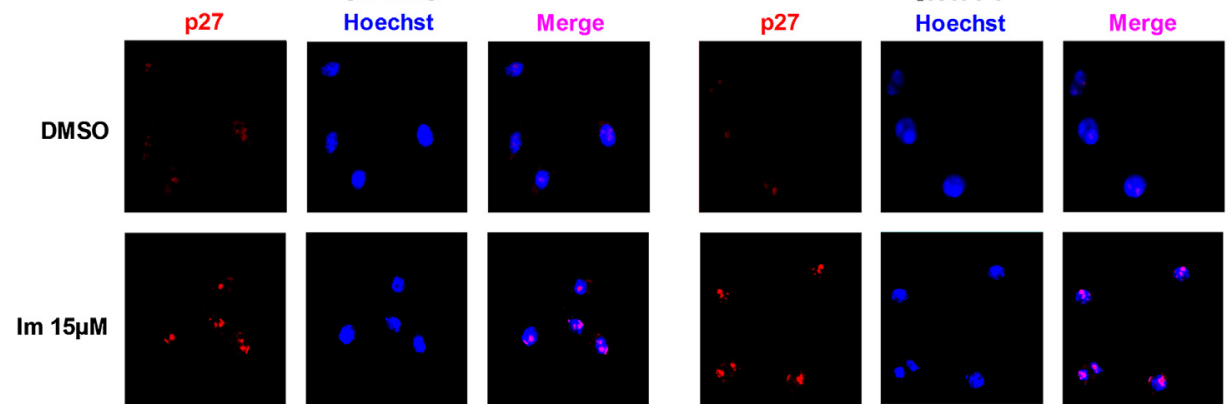

Fig. 1. Imatinib inhibits BrdU incorporation and promotes the upregulation of $\mathrm{p} 27^{\mathrm{KIP} 1}$ in the nuclear compartment.

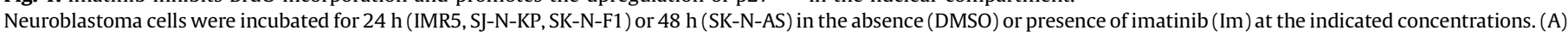

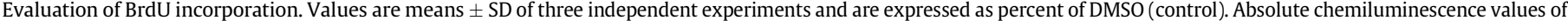

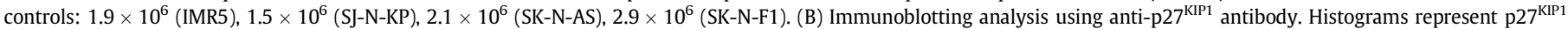

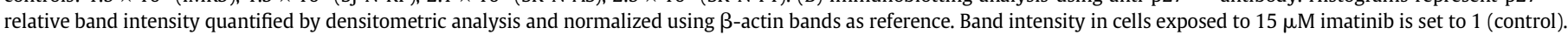

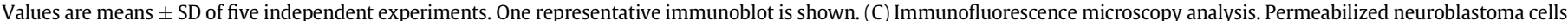

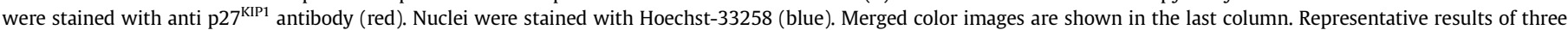

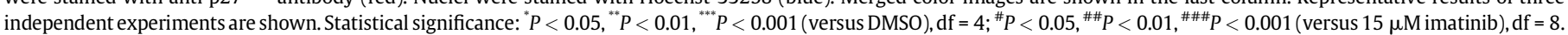


plasmid) or $150 \mu \mathrm{g}$ protein (imatinib treated cells or cells transfected with siRNAs or plasmid DNA) and incubated with rotation for $1 \mathrm{~h}$ at $4{ }^{\circ} \mathrm{C}$. Supernatant was removed, beads were washed twice with $500 \mu \mathrm{L}$ PBS containing $0.02 \%(\mathrm{v} / \mathrm{v}$ ) Tween-20, and proteins were eluted with $30 \mu \mathrm{L} 0.1 \mathrm{M}$ citrate $\mathrm{pH}$ 3.1. Following neutralization with $20 \mu \mathrm{L} 1 \mathrm{M}$ Tris $\mathrm{pH}$ 9, eluted proteins were mixed 1:1 with Laemmli sample buffer and subjected to immunoblot analysis. To verify the specificity of phospho-cAbl Tyr-245 antibody, c-Abl immunoprecipitates were treated for $2 \mathrm{~h}$ at $37^{\circ} \mathrm{C}$ with $10 \mathrm{U}$ alkaline phosphatase (AP+) (P-4252, Sigma, Milan, Italy) or vehicle (AP-), mixed 1:1 with Laemmli sample buffer, heated at $95{ }^{\circ} \mathrm{C}$ for $5 \mathrm{~min}$, before immunoblot analysis.

\subsection{Immunofluorescence microscopy}

Cells $\left(1 \times 10^{5}\right)$ were fixed in $4 \%(\mathrm{w} / \mathrm{v})$ paraformaldehyde in PBS for $30 \mathrm{~min}$, washed with PBS, permeabilized with PBS containing $0.1 \%(\mathrm{v} / \mathrm{v})$ Triton $\mathrm{X}-100$ and $15 \mathrm{mM} \mathrm{NaN}_{3}$ (PBS-Triton buffer), and blocked in PBS-Triton buffer containing 2\% (w/v) BSA for $1 \mathrm{~h}$. Cells were incubated overnight at $4{ }^{\circ} \mathrm{C}$ with the primary antibody (sc-528) diluted 1:500 in PBS-Triton buffer, washed with PBS-Triton buffer, and incubated for $1 \mathrm{~h}$ with Cy3conjugated goat anti-rabbit secondary antibody (AP132C, Millipore, Milan, Italy) diluted $1: 1000$ in PBS-Triton buffer. Nuclei were stained for $20 \mathrm{~min}$ in the dark with Hoechst-33258 (861405, Sigma, Milan, Italy) to a final concentration of $500 \mathrm{ng} / \mathrm{mL}$. Images were acquired using a Leica DMI $4000 \mathrm{~B}$ inverted microscope (Milan. Italy).

\subsection{RNA interference}

siRNAs targeting the human forms of CDK2 or $\mathrm{p} 27^{\mathrm{KIP} 1}$ or $\mathrm{c}-\mathrm{Abl}$ and control nontargeting siRNA (1027280, AllStar negative control) were purchased from Qiagen, Milan, Italy. Two CDK2 targeting siRNAs (SI00299775; SI02654638), two p27 $7^{\text {KIP1 }}$ targeting siRNAs (SI02621990; SI02621997) and four c-Abl targeting siRNAs (SI00288316; SI00288323; SI00299082; SI00299089) were tested individually. Neuroblastoma cells $\left(2 \times 10^{6}\right)$ were transfected in a volume of $100 \mu \mathrm{L}$ with 3 pmol siRNA using Amaxa Nucleofector device (Lonza, Rome, Italy). Nucleofector kit V and program C-005 were used for IMR5 and SJ-N-KP cells; nucleofector kit V and program X-005 were used for SK-N-F1 cells; nucleofector kit T and program B-013 were used for SK-N-AS cells. Following transfection, cells were cultured for $24 \mathrm{~h}$ before further treatments or expression analysis.

\subsection{Real-time $P C R$}

Total RNA was extracted from $2 \times 10^{6}$ cells, and converted to cDNA as previously described [24]. Primers were designed using Primer3 (http://frodo.wi.mit.edu) and synthesized by MWG (Martinsried, Germany). SKP2 mRNA (NM_005983.3) was amplified from 749 to 962 with primers forward $5^{\prime}$-catttcagccettttcgtgt$3^{\prime}$ and reverse $5^{\prime}$-gggcaaattcagagaatcca-3'. CCNA2 (cyclin A) mRNA (NM_001237.3) was amplified from 1366 to 1587 with primers forward $5^{\prime}$-ttattgctggagctgccttt- $3^{\prime}$ and reverse $5^{\prime}$-ctggtgggttgagga-

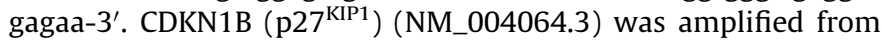
836 to 1008 with primers forward $5^{\prime}$-ccggctaactctgaggacac- $3^{\prime}$ and reverse $5^{\prime}$-ggggaaccgtctgaaacatt- $3^{\prime}$. ACTB (beta cytoskeletal actin) mRNA (NM_001101.3) was amplified from 698 to 969 with primers forward $5^{\prime}$-agcgggaaatcgtgcgtgacatta- $3^{\prime}$ and reverse $5^{\prime}$ ggcgtacaggtctttgcggatgtc- $3^{\prime}$. Relative transcript abundance was calculated by CFX Manager software (Bio-Rad, Milan, Italy) using the $\Delta \Delta C_{\mathrm{t}}$ method with ACTB as the reference gene. All samples were assayed in triplicate.

\subsection{Cloning and site-directed mutagenesis}

Plasmids encoding human full-length pRb (IMAGE ID: 5267622) and p27 ${ }^{\mathrm{KIP} 1}$ (IMAGE ID: 3458141) were obtained from Source Bioscience (Nottingham, UK) and purified from bacterial cultures using a Plasmid Midi Kit (12143, Qiagen, Milan, Italy). The human $\mathrm{p} 27^{\mathrm{KIP} 1}$ coding sequence was amplified using Pfu thermostable DNA polymerase (600670-51, Agilent, Milan, Italy) in the presence of the forward primer $5^{\prime}$-caccatgtcaaacgtgcgagtgtctaac- $3^{\prime}$, in which the $5^{\prime}$-cacc- $3^{\prime}$ sequence comprising the topoisomerase I recognition site was fused to the sequence corresponding to positions $473-496$ of human $\mathrm{p} 27^{\mathrm{KIP} 1} \mathrm{mRNA}$ (NM_004064.3), and the reverse primer 5'-ttacgtttgacgtcttctgaggccag-3' corresponding to positions 1044-1069. A sequence coding for a truncated form of human $\mathrm{pRb}(\mathrm{pRb} \Delta 882)$ comprising amino acids 373-882 was amplified using Pfu thermostable DNA polymerase in the presence of the forward primer $5^{\prime}$-caccatgactccagttaggactgttatg- $3^{\prime}$, in which the $5^{\prime}$-cacc-3' sequence was fused to the sequence corresponding to positions 1283-1303 of human $\mathrm{pRb}$ mRNA (NM_000321.2), and the reverse primer 5'-tcatgatccttcaatatcaaagcgtagtt-3' corresponding to positions 2787-2812. The amplification products were gel-purified using the Qiaquick Gel Extraction Kit (28704, Qiagen, Milan, Italy), subcloned into pcDNA3.1 directional TOPO expression vector (K4900-01, Life Technologies, Milan, Italy), and transformed into Top 10 chemically

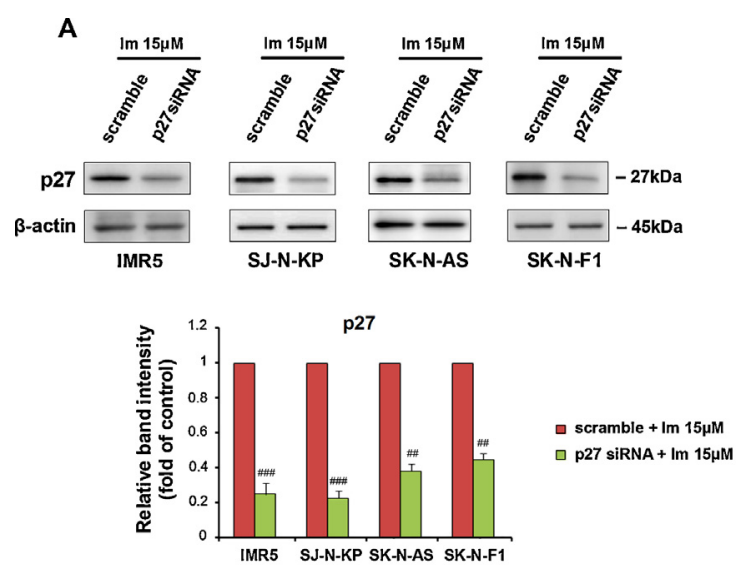

B

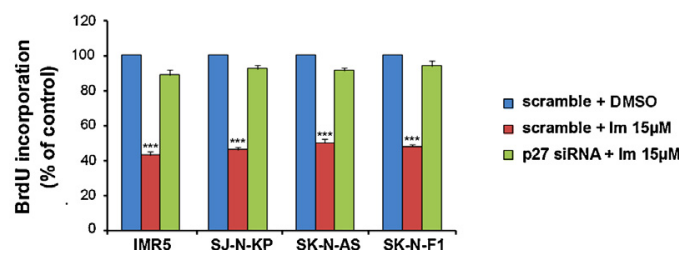

Fig. 2. Knockdown of $\mathrm{p} 27^{\mathrm{KIP} 1}$ impairs the antiproliferative effect of imatinib. Neuroblastoma cells were transfected with p27 $7^{\mathrm{KIP} 1}$-targeting siRNAs or nontargeting control siRNA (scramble). After $24 \mathrm{~h}$ from transfection, cells were treated with $15 \mu \mathrm{M}$ imatinib for additional $24 \mathrm{~h}$ (IMR5, SJ-N-KP, SK-N-F1) or $48 \mathrm{~h}$ (SK-NAS). (A) Evaluation of $\mathrm{p} 27^{\mathrm{KIP} 1}$ expression by immunoblot analysis. Histograms represent $\mathrm{p} 27^{\mathrm{KIP} 1}$ relative band intensity quantified by densitometric analysis and normalized using $\beta$-actin bands as reference. Band intensity in scramble exposed to $15 \mu \mathrm{M}$ imatinib is set to 1 (control). Values are means \pm SD of three independent experiments. One representative immunoblot is shown. (B) Evaluation of BrdU incorporation. Values are means \pm SD of three independent experiments and are expressed as percent of BrdU incorporation in cells transfected with scramble and exposed to DMSO (control). Absolute chemiluminescence values of controls: $1.2 \times 10^{6}$ (IMR5), $1.1 \times 10^{6}(\mathrm{SJ}-\mathrm{N}-\mathrm{KP}), 1.2 \times 10^{6}$ (SK-N-AS), $1.2 \times 10^{6}$ (SK-N-F1). Statistical significance: ${ }^{\# \# P}<0.01$, ${ }^{\# \# \#} P<0.001$ (versus scramble $+15 \mu \mathrm{M}$ imatinib), df $=4$; ${ }^{* * * *} P<0.001$ (versus scramble + DMSO), df $=4$.

Comparable results were obtained when cells were transfected with a pool of two p $27^{\text {KIP1 }}$-targeting siRNAs or when each siRNA was used individually. 
competent Escherichia coli cells. After isolation of positive transformants, plasmids were purified from bacterial cultures using EndoFree Plasmid Kit (12362, Qiagen, Milan, Italy) and sequenced at MWG. The purified plasmids were dissolved in sterile TE buffer (10 mM Tris pH 7.6, $1 \mathrm{mM}$ EDTA). Plasmid coding for a mutant nonphosphorylatable form of p27 ${ }^{\mathrm{KIP} 1}$ (p27 Y88F/Y89F) was obtained using QuikChange Multi Site-Directed Mutagenesis Kit (200514, Agilent, Milan, Italy) in the presence of the primer $5^{\prime}$ agcttgcccgagttcttcttcagaccccogc- $3^{\prime}$. Automated sequencing confirmed that the expected mutations were introduced into the sequence. For recombinant protein expression, neuroblastoma cells $\left(2 \times 10^{6}\right)$ were transfected with $3 \mu \mathrm{g}$ of the indicated plasmid or empty vector using Amaxa Nucleofector as described in section 2.5 .

\subsection{Caspase 3/7 activity assay}

Cells $\left(2 \times 10^{4} /\right.$ well $)$ were seeded in $100 \mu \mathrm{L}$ complete medium into a black 96 well culture plate, treated with $15 \mu \mathrm{M}$ imatinib or drug vehicle (DMSO) for $24 \mathrm{~h}$ (IMR5, SJ-N-KP, SK-N-F1) or $48 \mathrm{~h}$

A

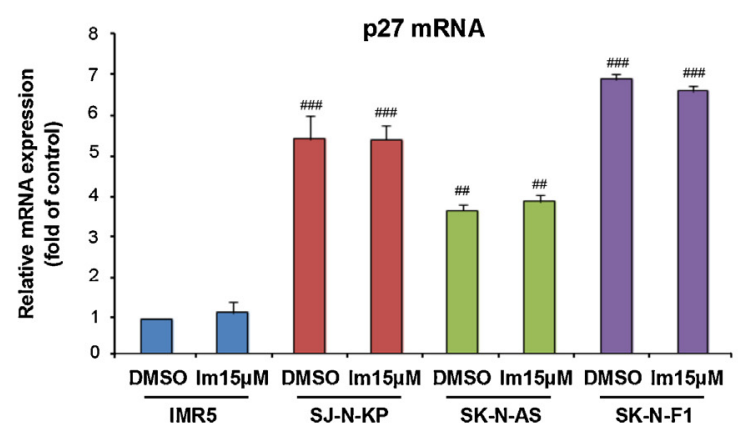

B
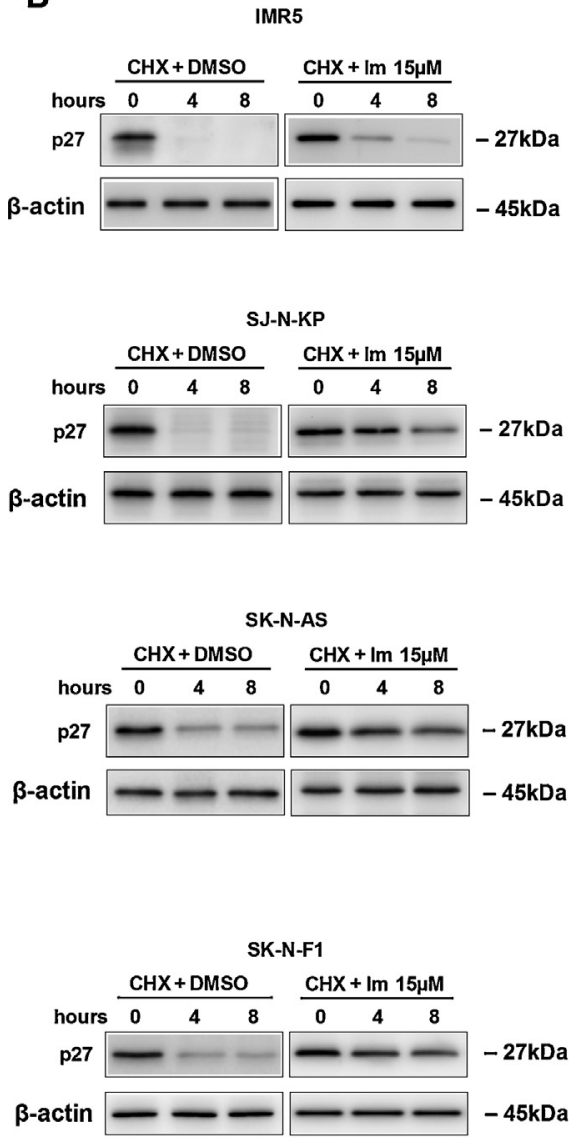

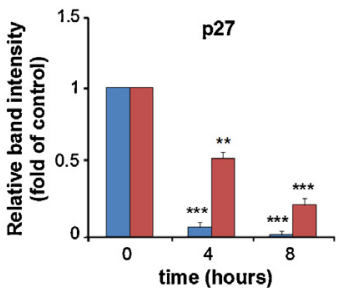

- $\mathrm{DMSO}+\mathrm{CHX}$

- $\operatorname{Im} 15 \mu \mathrm{M}+\mathrm{CHX}$

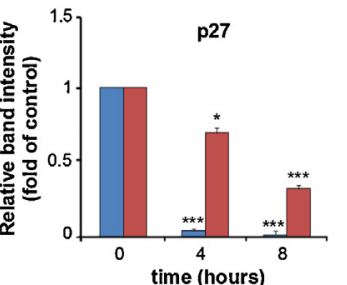

p27

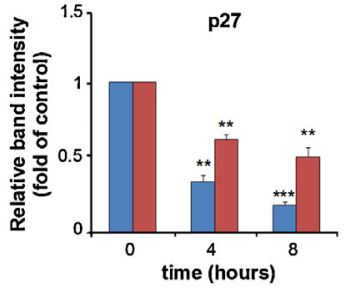

- DMSO + CHX

- $\operatorname{Im} 15 \mu \mathrm{M}+\mathrm{CHX}$

$\mathrm{DMSO}+\mathrm{CHX}$

- $\operatorname{Im} 15 \mu \mathrm{M}+\mathrm{CHX}$

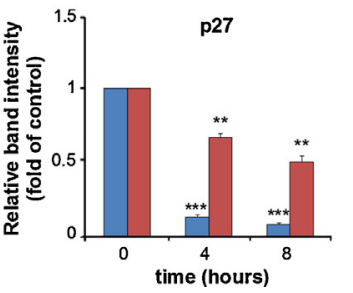

- DMSO + CHX

- $\operatorname{Im} 15 \mu \mathrm{M}+\mathrm{CHX}$

Fig. 3. Imatinib promotes $\mathrm{p} 27^{\mathrm{KIP} 1}$ upregulation as a result of $\mathrm{p} 27^{\mathrm{KIP} 1}$ protein stabilization.

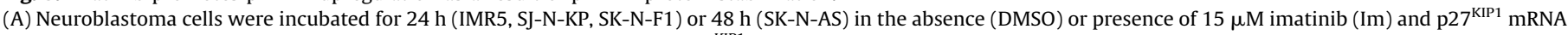

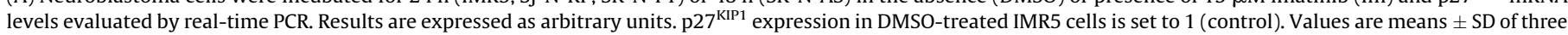

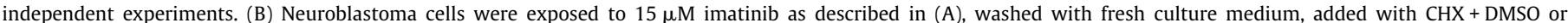

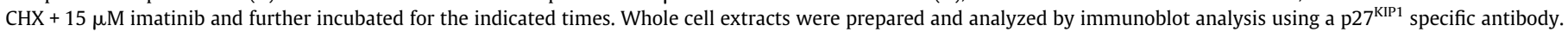

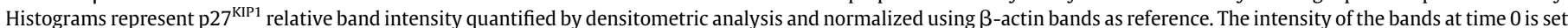

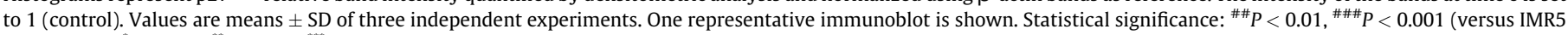
cells), df $=4$; ${ }^{*} P<0.05,{ }^{* *} P<0.01,{ }^{* * *} P<0.001$ (versus time 0 ), $\mathrm{df}=4$. 
(SK-N-AS) and cultured at $37{ }^{\circ} \mathrm{C}$ for $24 \mathrm{~h}$ in a $5 \% \mathrm{CO}_{2}$ humidified atmosphere. As positive control, cells were treated with $20 \mathrm{nM}$ epoxomicin (EPX) (sc-201298, SantaCruz, Heidelberg, Germany) for $24 \mathrm{~h}$ (IMR5, SJ-N-KP, SK-N-F1) or $48 \mathrm{~h}$ (SK-N-AS) [25]. At the end of incubation $100 \mu \mathrm{L}$ of Apo-ONE Homogeneous Caspase-3/7 Reagent (Promega, Milan, Italy) was added in each well. The plate was mixed for $5 \mathrm{~min}$ on a plate shaker at $300-500 \mathrm{rpm}$ and incubate at room temperature for $10 \mathrm{~h}$. Fluorescence was measured in each well at $485 \mathrm{~nm}$ (excitation) and $530 \mathrm{~nm}$ (emission) using a Fluoroskan Ascent-Thermo microplate fluorometer (Thermo-Fisher Scientific, Milan, Italy).

\subsection{Statistical analysis}

Student's $t$-test was used for statistical comparison of differences. $P<0.05$ was considered significant.
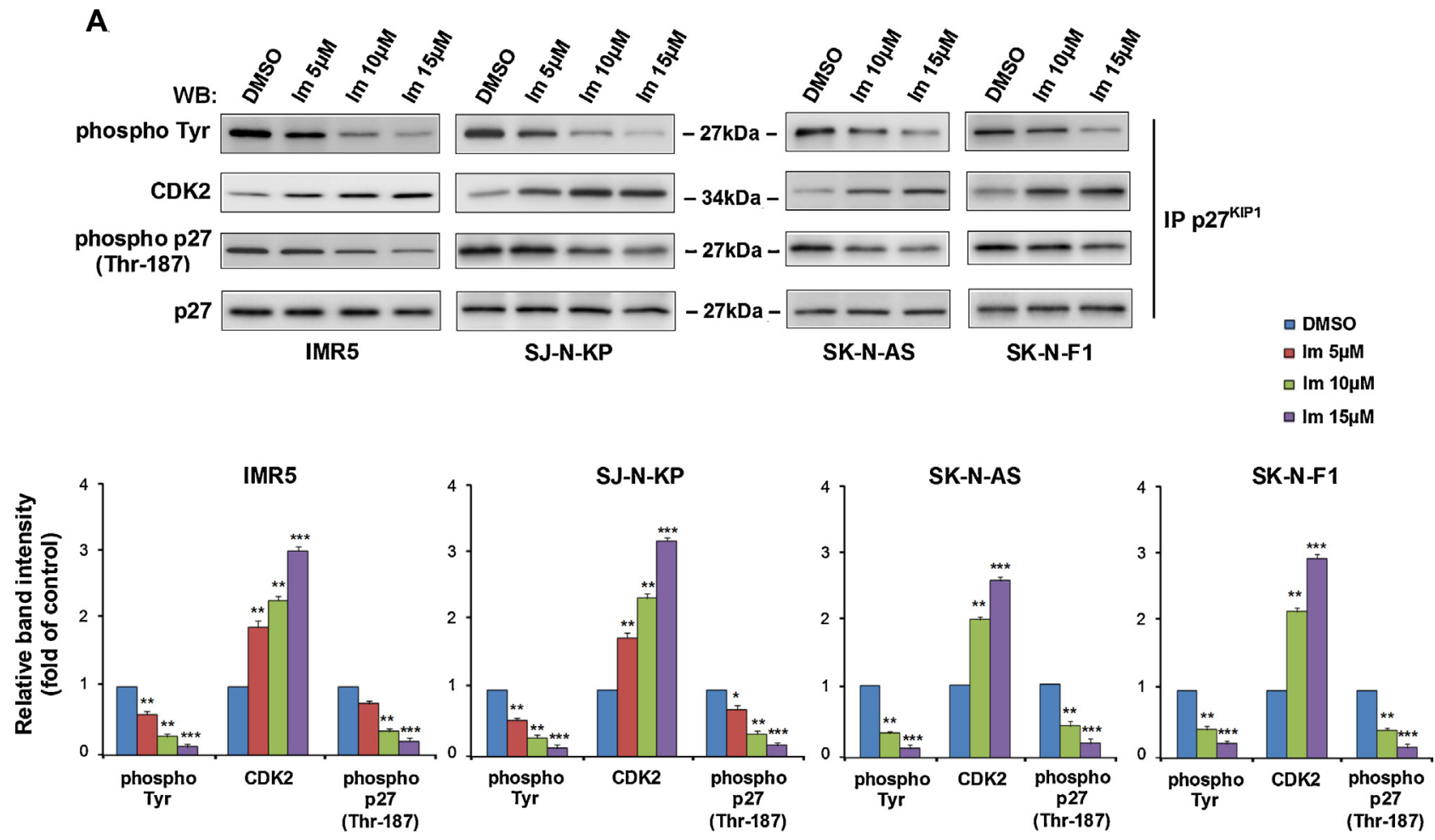

B
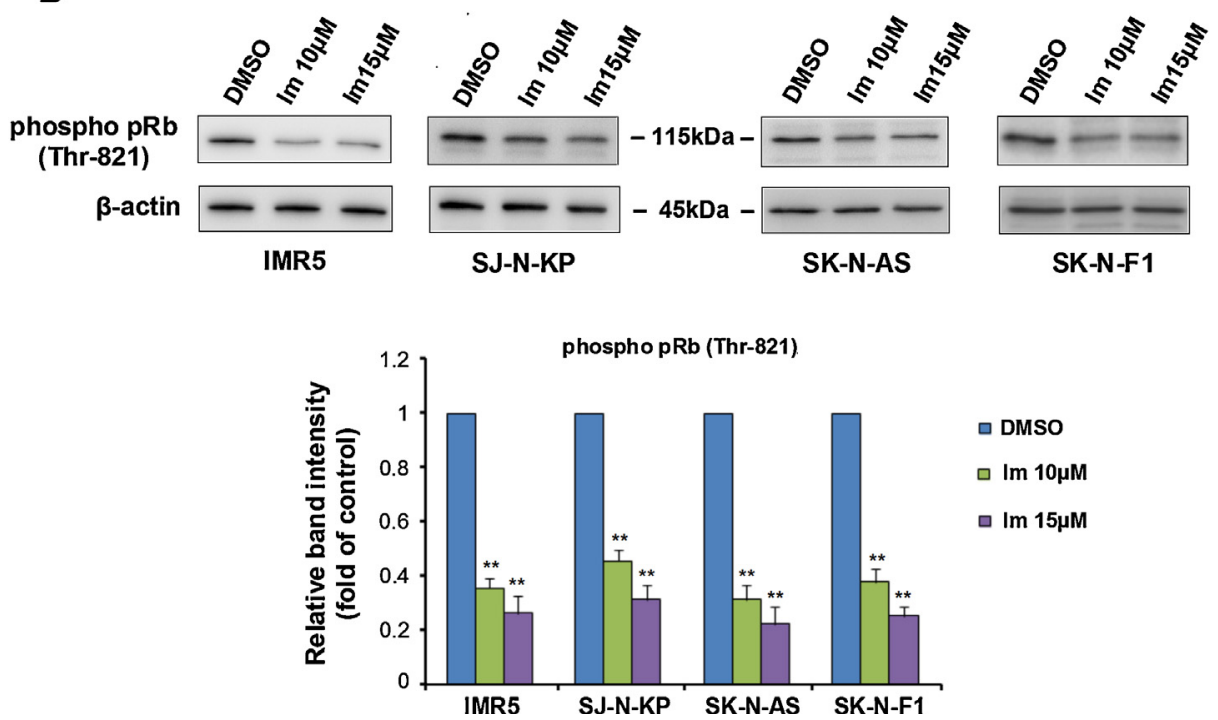

Fig. 4. Effects of imatinib on $\mathrm{p} 27^{\mathrm{KIP} 1}$ phosphorylation on tyrosine residues and Thr- 187 .

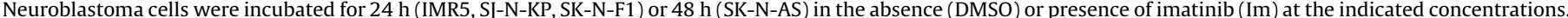

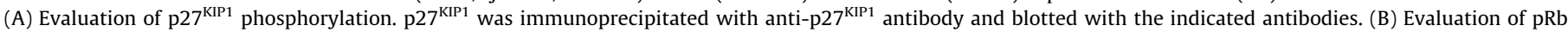

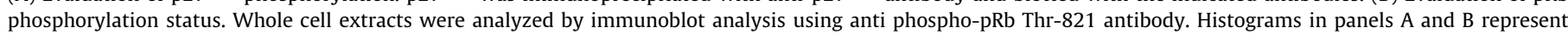

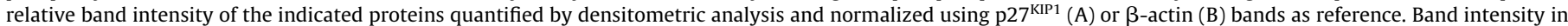

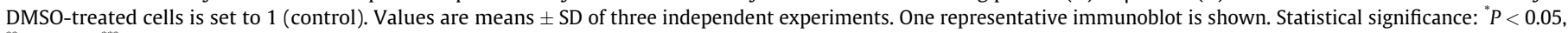
${ }^{* *} P<0.01,{ }^{* * * *} P<0.001$ (versus DMSO), df $=4$. 


\section{Results}

3.1. Imatinib inhibits BrdU incorporation and promotes the upregulation of $p 27^{K I P 1}$ in the nuclear compartment

Exposure of IMR5, SJ-N-KP, SK-N-F1 and SK-N-AS neuroblastoma cell lines to 1-15 $\mu \mathrm{M}$ imatinib, resulted in a dose dependent inhibition of BrdU incorporation into newly synthesized DNA (Fig. 1A). A $24 \mathrm{~h}$ period of drug exposure was used for IMR5, SJ-NKP and SK-N-F1 cells. At variance, exposure of SK-N-AS cells to imatinib was prolonged to $48 \mathrm{~h}$ to reach an inhibitory effect comparable with that of the other three cell lines. No activation of caspase-3/7 or PARP degradation was detected in imatinib treated cells (not shown), thus excluding apoptosis as the cause of reduced BrdU incorporation. Taken together, these results suggest an impairment in $\mathrm{G} 1$ to $\mathrm{S}$ phase transition. No changes in the expression of cyclin E and CDK2 or cyclin D1 and CDK4/6 which regulate $S$ phase entry [26] were revealed in imatinib treated cells (not shown). At variance, a dose dependent increase in the expression of the CDK inhibitor $\mathrm{p} 27^{\mathrm{KIP} 1}$ was detected (Fig. 1B). Fluorescence microscopy analysis provided evidence of nuclear localization of $\mathrm{p} 27^{\mathrm{KIP} 1}$ in imatinib treated cells (Fig. 1C). To further

A
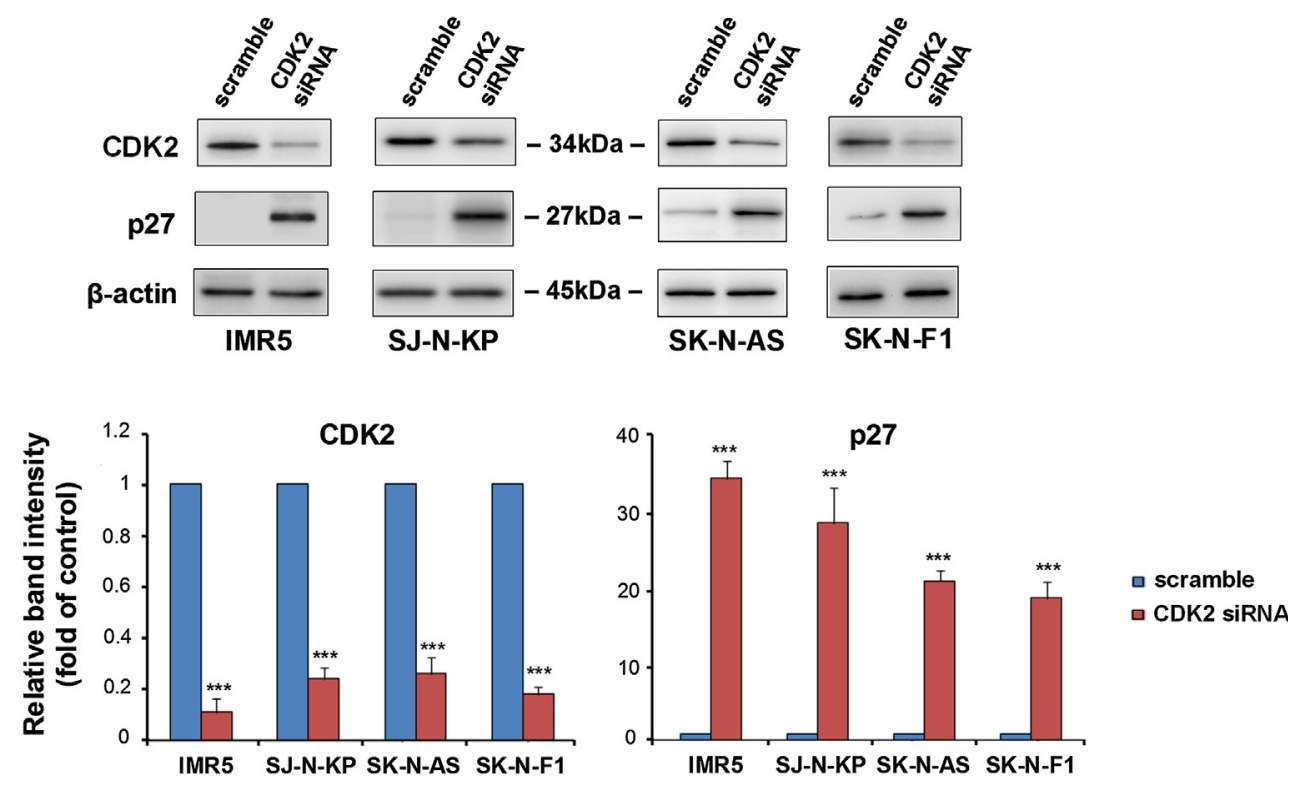

B
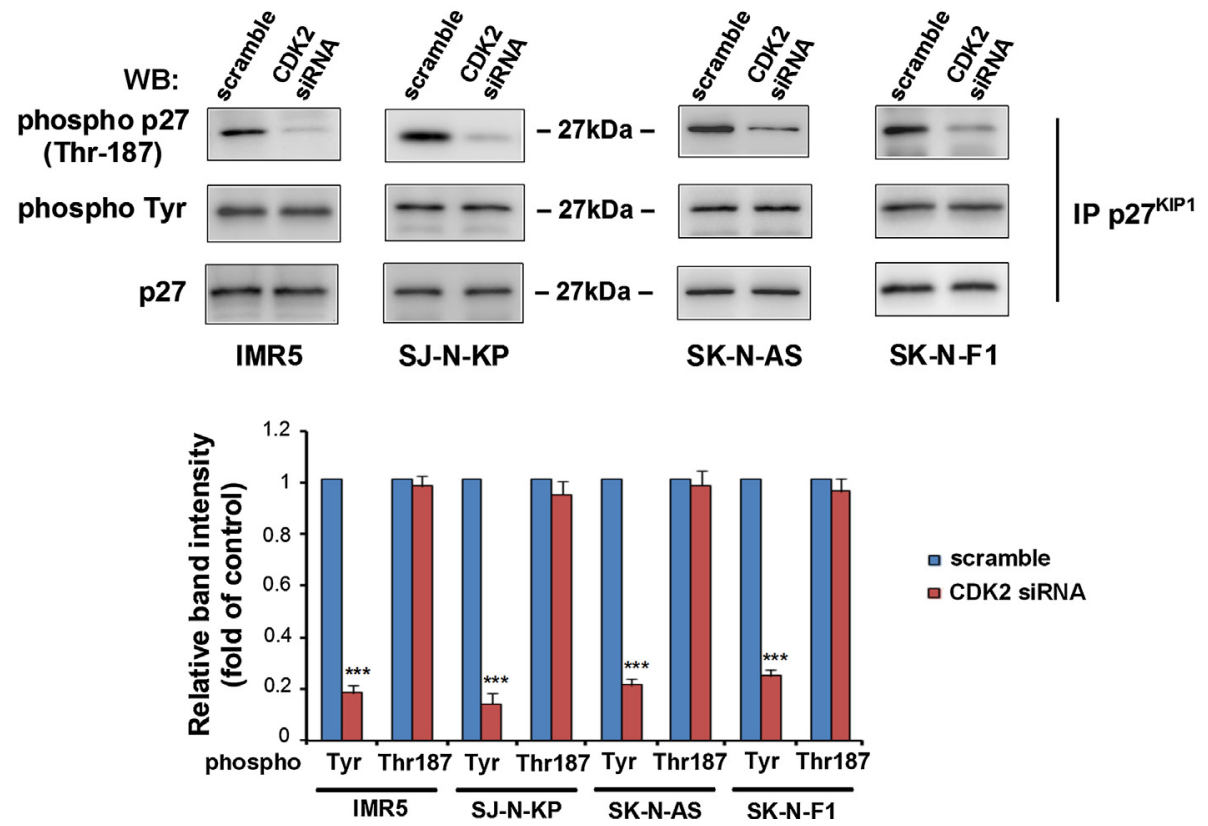

Fig. 5. CDK2 knockdown reveals constitutive phosphorylation of $\mathrm{p} 27^{\mathrm{KIP} 1}$ on tyrosine residues.

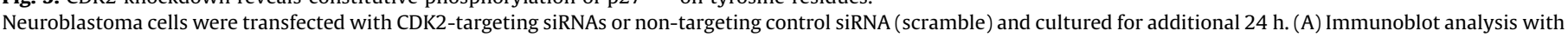

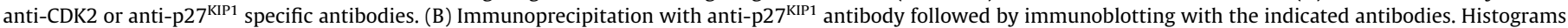

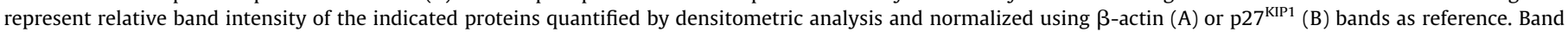

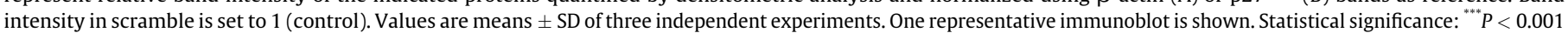
(versus scramble), df $=4$.

Comparable results were obtained when cells were transfected with a pool of two CDK2-targeting siRNAs or when each siRNA was used individually. 

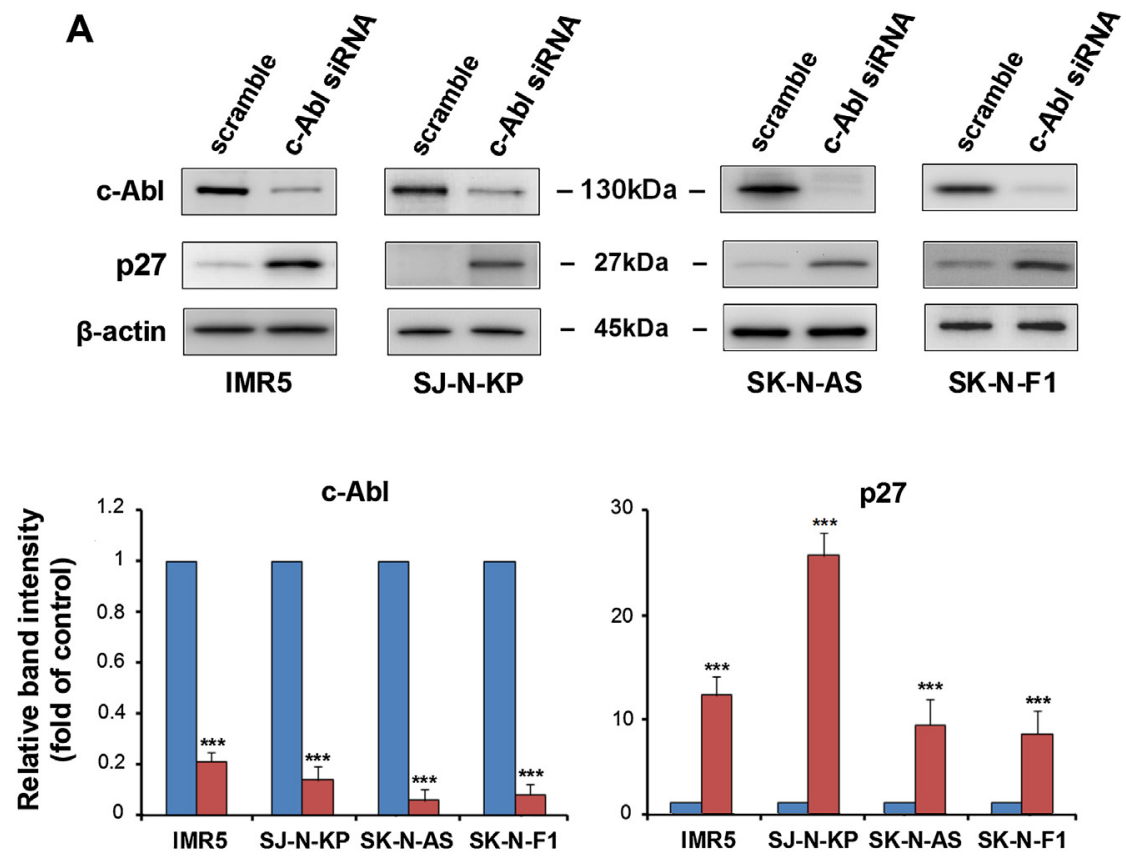

$$
\begin{aligned}
& \square \text { scramble } \\
& \square \text { c-Abl siRNA }
\end{aligned}
$$

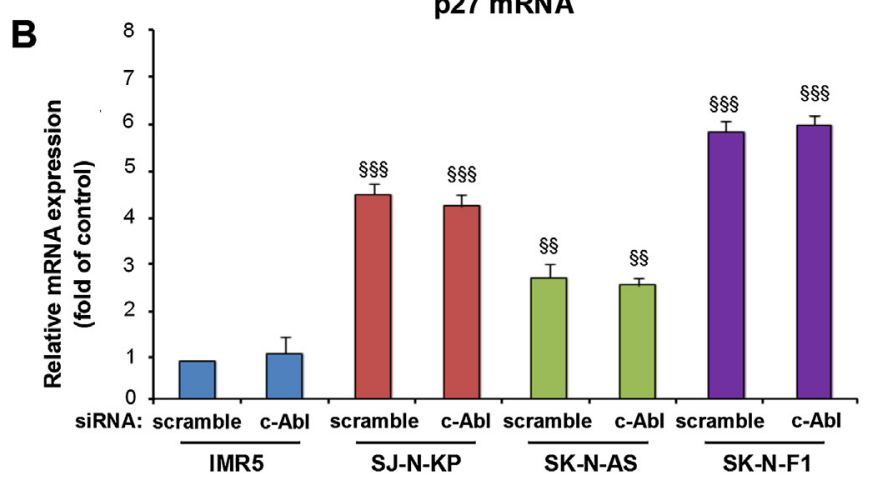

C

D
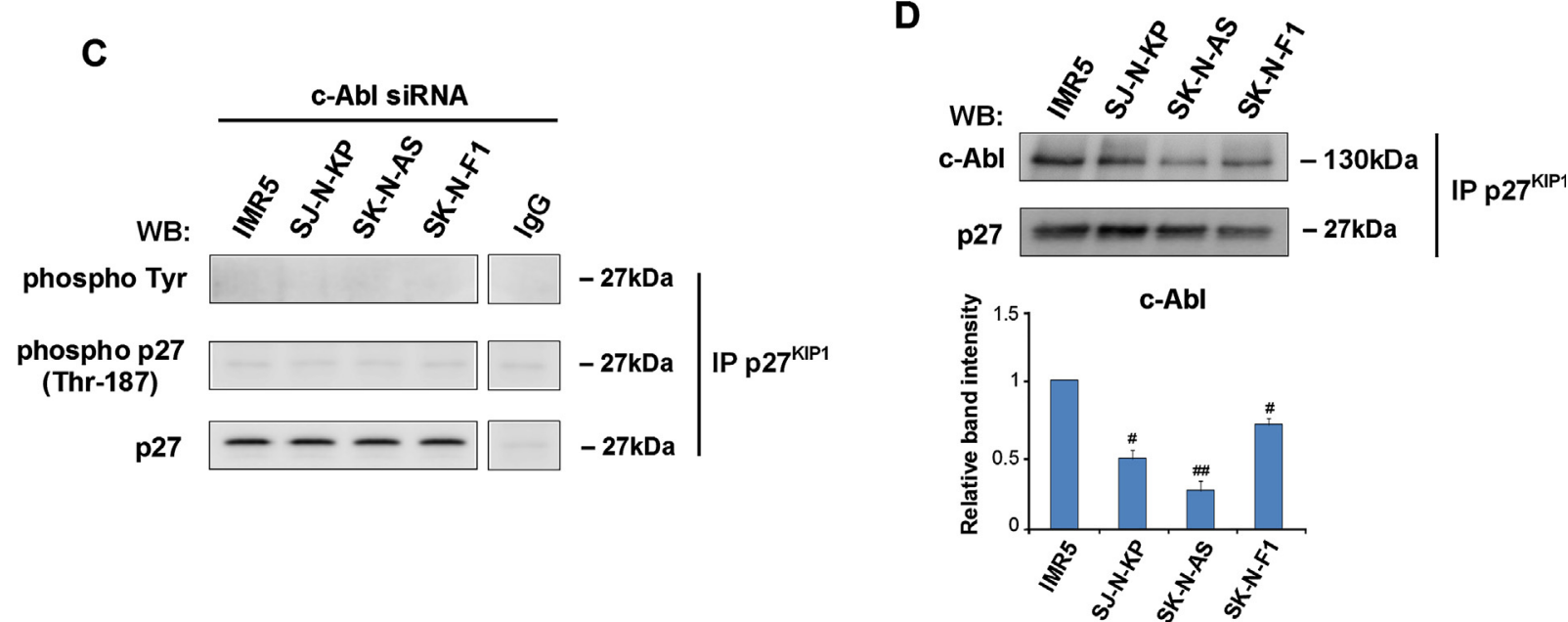

Fig. 6. Effects of c-Abl knockdown on $\mathrm{p} 27^{\mathrm{KIP} 1}$ expression and phosphorylation status.

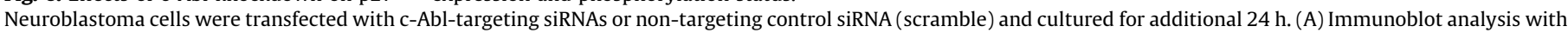

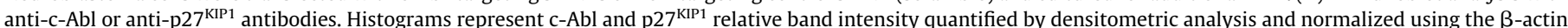

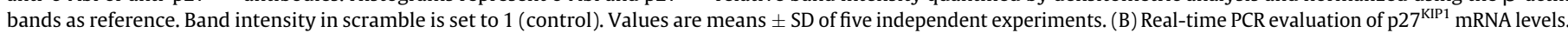

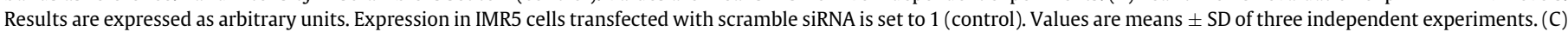

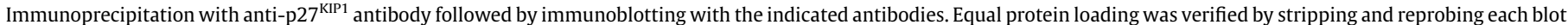

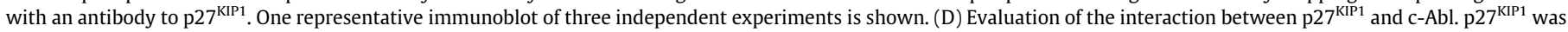

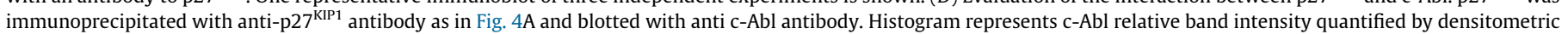


investigate the dependence of the antiproliferative effect of imatinib on $\mathrm{p} 27^{\mathrm{KIP} 1}$, the expression of $\mathrm{p} 27^{\mathrm{KIP} 1}$ was downregulated by siRNA-mediated gene silencing (Fig. 2A). Noteworthy, in neuroblastoma cells depleted of p27 ${ }^{\mathrm{KIP} 1}$ the inhibitory effect of $15 \mu \mathrm{M}$ imatinib on BrdU incorporation did not reach statistical significance, thus excluding a direct inhibitory effect of imatinib on BrdU incorporation (Fig. 2B). To determine the mechanism of p2 $7^{\mathrm{KIP} 1}$ upregulation, mRNA expression and protein stability were investigated. In all cell lines, no significant changes in p27 KIP1 mRNA levels were detected by real-time PCR assays between DMSO and imatinib treated cells (Fig. 3A). In contrast, cycloheximide chase analysis evidenced an increased $\mathrm{p} 27^{\mathrm{KIP} 1}$ protein stability in cells exposed to imatinib (Fig. 3B). Taken together, these results support the conclusion that the antiproliferative effect of imatinib on neuroblastoma cells relies on $\mathrm{p} 27^{\mathrm{KIP} 1}$ upregulation in the nuclear compartment caused by increased $\mathrm{p} 27^{\mathrm{KIP} 1}$ protein stability.

3.2. Exposure to imatinib decreases $p 27^{\text {KIP1 }}$ phosphorylation on Thr187 and tyrosine residues

Cyclin E-CDK2-dependent phosphorylation at Thr-187 plays a well established role in the regulation of $\mathrm{p} 27^{\mathrm{KIP} 1}$ protein stability [27]. Moreover, recent results suggest that $\mathrm{p} 27^{\mathrm{KIP} 1}$ phosphorylation on Thr-187 is primed by phosphorylation on tyrosine residues by non-receptor tyrosine kinases [4]. To study this, p2 $7^{\mathrm{KIP} 1}$ was immunoprecipitated from neuroblastoma cells exposed to 10 or $15 \mu \mathrm{M}$ imatinib or drug vehicle and blotted using anti phosphop2 $7^{\text {KIP1 }}$ Thr-187 or anti phospho-tyrosine specific antibodies. As shown in Fig. 4A, a dose dependent decrease in p $27^{\mathrm{KIP} 1}$ phosphoThr-187 and phospho-tyrosine content was detected in cells exposed to imatinib. Moreover, in agreement with the notion that binding of $\mathrm{p} 27^{\mathrm{KIP} 1}$ to cyclin-CDK2 is inversely related to $\mathrm{p} 27^{\mathrm{KIP} 1}$ tyrosine phosphorylation [28], a dose dependent increase in the amount of CDK2 was observed in $\mathrm{p} 27^{\mathrm{KIP} 1}$ immunoprecipitates from imatinib treated cells. Collectively, these results are consistent with a model in which imatinib by inhibiting $\mathrm{p} 27^{\mathrm{KIP} 1}$ phosphorylation on tyrosine residues restores $\mathrm{p} 27^{\mathrm{KIP} 1}$ inhibitory activity on CDK2, resulting in decreased Thr-187 phosphorylation. In agreement with this hypothesis, in neuroblastoma cells exposed to imatinib, the phosphorylation of $\mathrm{pRb}$ at the CDK2 specific Thr821 [29] was consistently reduced (Fig. 4B).

\subsection{In neuroblastoma cells $p 27^{K I P 1}$ is constitutively phosphorylated on tyrosine residues}

To investigate the mechanism of $\mathrm{p} 27^{\mathrm{KIP} 1}$ tyrosine phosphorylation, neuroblastoma cells were transfected with CDK2-targeting siRNAs, in order to suppress Thr-187 phosphorylation. As shown in Fig. 5A, depletion of CDK2 resulted in the upregulation $\mathrm{p} 27^{\mathrm{KIP} 1}$ which contained a greatly decreased amount of phosphorylated Thr-187 but unchanged levels of phosphotyrosine (Fig. 5B). Taken together, these results are consistent with the conclusion that in neuroblastoma cells $\mathrm{p} 27^{\mathrm{KIP} 1}$ is constitutively phosphorylated on tyrosine residues and indicate that $\mathrm{p} 27^{\mathrm{KIP} 1}$ tyrosine phosphorylation is independent of Thr-187 phosphorylation.

\subsection{Silencing of $c$-Abl recapitulates the effects of imatinib on $p 27^{\text {KIP1 }}$ expression levels}

To investigate the potential involvement of $\mathrm{c}-\mathrm{Abl}$ in $\mathrm{p} 27^{\mathrm{KIP} 1}$ tyrosine phosphorylation, neuroblastoma cells were transfected with c-Abl-targeting siRNAs. As shown in Fig. 6A and B, depletion of c-Abl resulted in the upregulation of $\mathrm{p} 27^{\mathrm{KIP} 1}$ in the absence of significant changes in p27 $7^{\mathrm{KIP} 1} \mathrm{mRNA}$ levels. Importantly, in p27 $27^{\mathrm{KIP} 1}$ immunoprecipitates virtually no phosphotyrosine or phosphoThr-187 was detected, recapitulating the effects of imatinib (Fig. 6C). Taken together, these results highlight a so far unknown role for $\mathrm{c}-\mathrm{Abl}$ in the regulation of $\mathrm{p} 27^{\mathrm{KIP} 1}$ tyrosine phosphorylation in vivo and are consistent with the notion that phosphorylation on tyrosine residues primes $\mathrm{p} 27^{\mathrm{KIP} 1}$ for Thr-187 phosphorylation. In addition, these data support the conclusion that in neuroblastoma cells exposed to imatinib $\mathrm{p} 27^{\mathrm{KIP} 1}$ stabilization results from inhibition of c-Abl-dependent phosphorylation on tyrosine residues. Of note, analysis of $\mathrm{p} 27^{\mathrm{KIP} 1}$ immunoprecipitates from untransfected DMSO-treated neuroblastoma cells with anti cAbl antibody, evidenced significant amounts of c-Abl, indicating a direct interaction between $\mathrm{p} 27^{\mathrm{KIP} 1}$ and c-Abl (Fig. 6D).

3.5. Expression of $p 27^{\mathrm{Y} 88 \mathrm{~F} / \mathrm{Y} 89 \mathrm{~F}}$ but not wild type $\mathrm{p} 27^{\mathrm{KIP} 1}$ recapitulates the effects of imatinib on BrdU incorporation

Tyr-88 and Tyr-89 are major phospho-acceptor sites of $\mathrm{p} 27^{\mathrm{KIP} 1}$ targeted by c-Abl [4,5]. To further test the effects of the loss of $\mathrm{p} 27^{\mathrm{KIP} 1}$ phosphorylation on tyrosine residues, neuroblastoma cells were transfected with a plasmid coding for a mutant form of $\mathrm{p} 27^{\mathrm{KIP} 1}$ (p27 $7^{\mathrm{Y} 88 \mathrm{~F} / \mathrm{Y} 89 \mathrm{~F}}$ ) which cannot be phosphorylated on Tyr-88 and Tyr-89 or wild type $\mathrm{p} 27^{\mathrm{KIP} 1}$. Transfection with $\mathrm{p} 27^{\mathrm{Y} 88 \mathrm{~F} / \mathrm{Y} 89 \mathrm{~F}}$ but not wild type $\mathrm{p} 27^{\mathrm{KIP} 1}$, resulted in the expression of a stable protein (Fig. 7A) which was devoid of phosphorylated Thr-187 (Fig. 7B) and recapitulated the effects of imatinib on BrdU incorporation (Fig. 7C). In addition, expression of $\mathrm{p} 27^{\mathrm{Y} 88 \mathrm{~F} / \mathrm{Y89F}}$ recapitulated the effects of imatinib on pRb phosphorylation at Thr-821 (Fig. 7D). These data support the conclusion that in neuroblastoma cells tyrosine phosphorylation negatively regulates $\mathrm{p} 27^{\mathrm{KIP} 1}$ stability and p $27^{\mathrm{KIP} 1}$ inhibitory activity on CDK2 and that suppression of $\mathrm{p} 27^{\mathrm{KIP} 1}$ phosphorylation on tyrosine residues exerts growth inhibitory effects on neuroblastoma cells.

\subsection{In neuroblastoma cells $c$-Abl is constitutively phosphorylated on} Tyr-245

To investigate c-Abl activation status, c-Abl was immunoprecipitated from cell extracts of exponentially growing neuroblastoma cells and immunoblotted using an antibody to phospho-c-Abl Tyr-245. As shown in Fig. 8A and B, Tyr-245 phosphorylated c-Abl was detected in all cell lines, suggesting that a significant fraction of cellular c-Abl is in an open and active conformation. The highest level of Tyr-245 phosphorylated c-Abl was detected in SK-N-AS cells. Exposure to imatinib did not affect c-Abl phosphorylation on Tyr-245 in any of the cell lines examined (Fig. 8C).

\subsection{Exposure to imatinib downregulates the expression of SKP2 and cyclin $A$}

Loss of phosphorylation on tyrosine residues converts $\mathrm{p} 27^{\mathrm{KIP} 1}$ from a bound non-inhibitor to a bound inhibitor of cyclin D-CDK4 complexes [5]. To evaluate the effects of imatinib on CDK4 activity, the phosphorylation status of pRb at the CDK4-specific Ser-780 [30] was investigated. As shown in Fig. 9A, in cells exposed to 10 and $15 \mu \mathrm{M}$ imatinib phosphorylation of Ser-780 was reduced, suggesting a decreased CDK4 activity. Collectively, the above reported results indicate that in imatinib treated cells $\mathrm{pRb}$ phosphorylation at CDK2- and CDK4-specific sites is reduced.

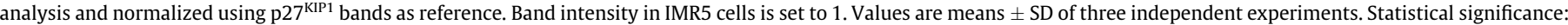
${ }^{* * * *} P<0.001$ (versus scramble), $\mathrm{df}=8$; ${ }^{\S \S} P<0.01,{ }^{\S \S} \mathrm{P} P 0.001$ (versus IMR5 cells transfected with scramble siRNA), df $=4$; ${ }^{\#} P<0.05$, ${ }^{\# \# P}<0.01$ (versus IMR5 cells), df $=4$. Comparable results were obtained when cells were transfected with a pool of four c-Abl-targeting siRNAs or when each siRNA was used individually. 


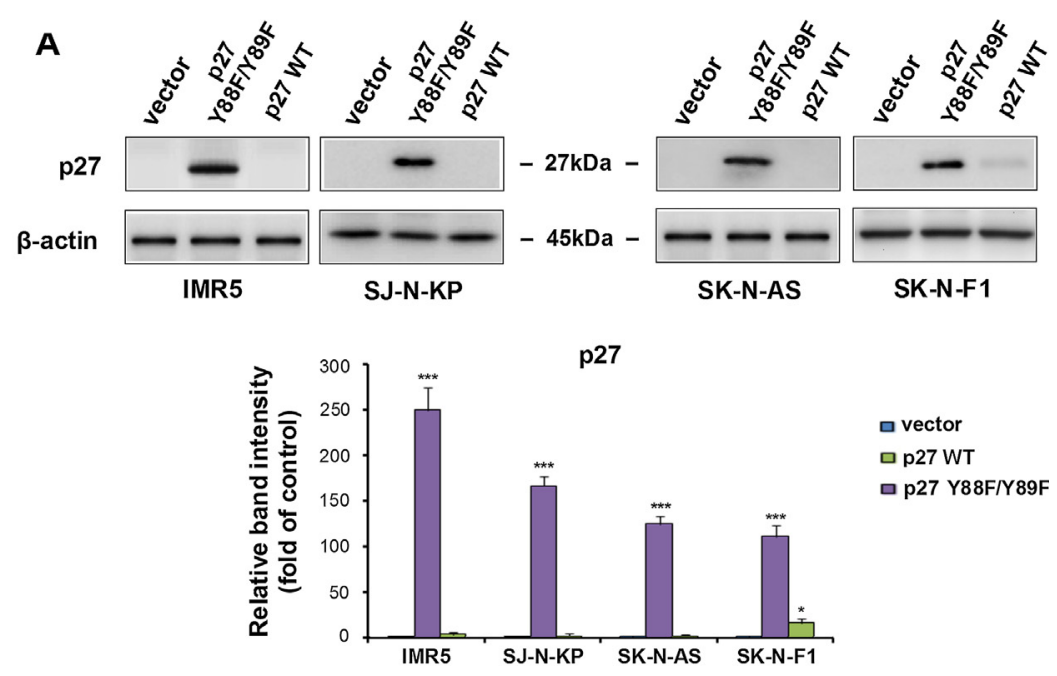

B

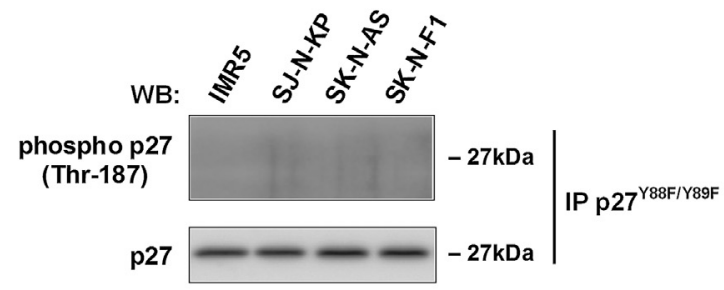

C

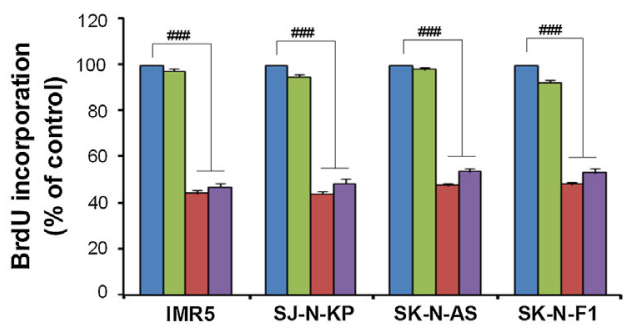

$\square$ vector + DMSO

$\square$ vector $+\operatorname{Im} 15 \mu \mathrm{M}$

口 p27 WT

ㅁ 27 Y88F/Y89F
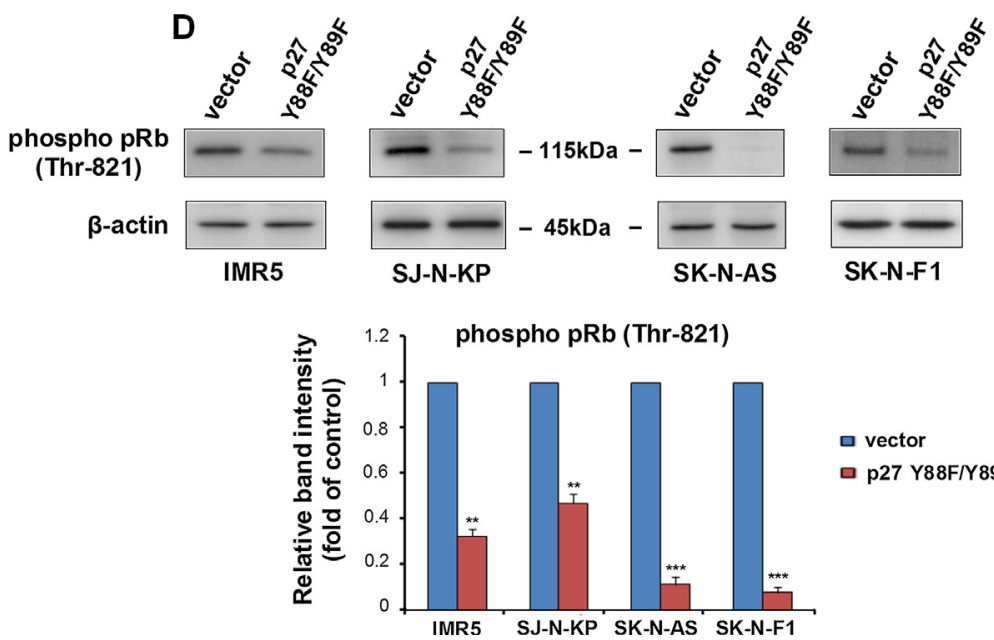

$\square$ vector

口 p27 Y88F/Y89F

Fig. 7. Effects of the expression of $\mathrm{p} 27^{\mathrm{Y} 88 \mathrm{~F} / \mathrm{Y} 89 \mathrm{~F}}$

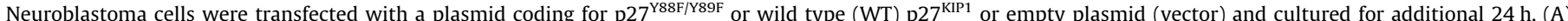

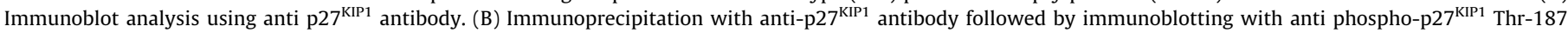

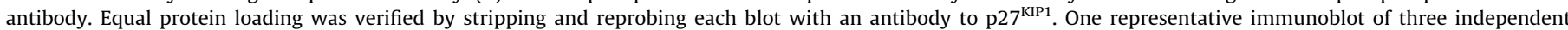

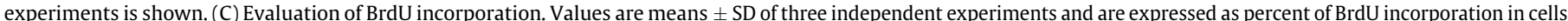

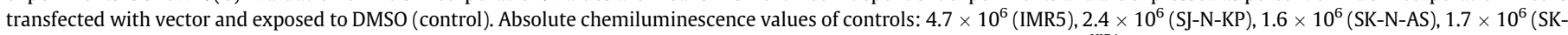

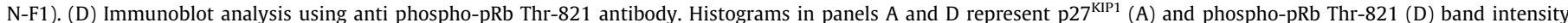

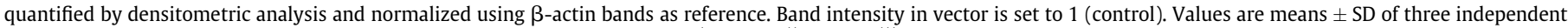

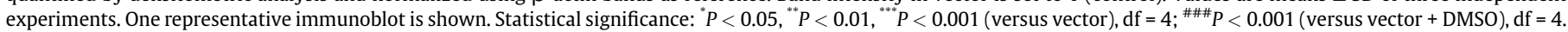


A

WB:

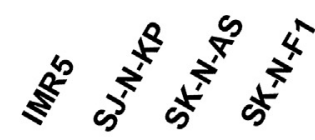

phospho c-Abl

(Tyr-245)

c-Abl

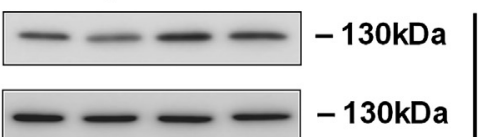

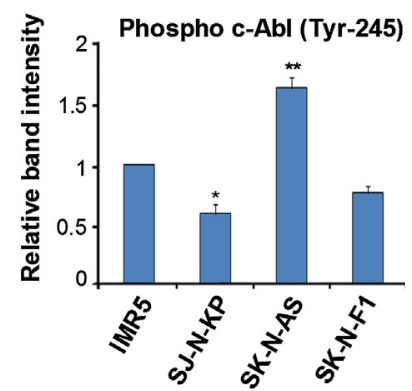

B

WB:
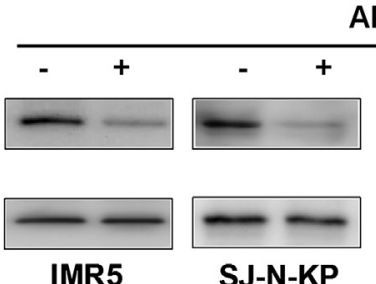

AP

phospho c-Abl

(Tyr-245)

c-Abl

IMR5

SJ-N-KP

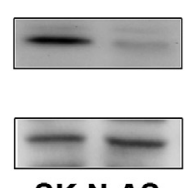

SK-N-AS

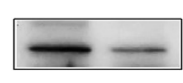

$-130 \mathrm{kDa}$

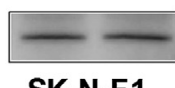

$-130 \mathrm{kDa}$

IP c-AbI

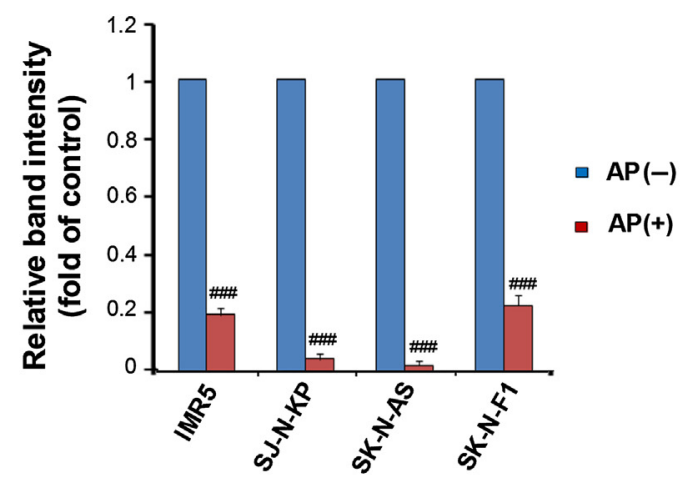

C

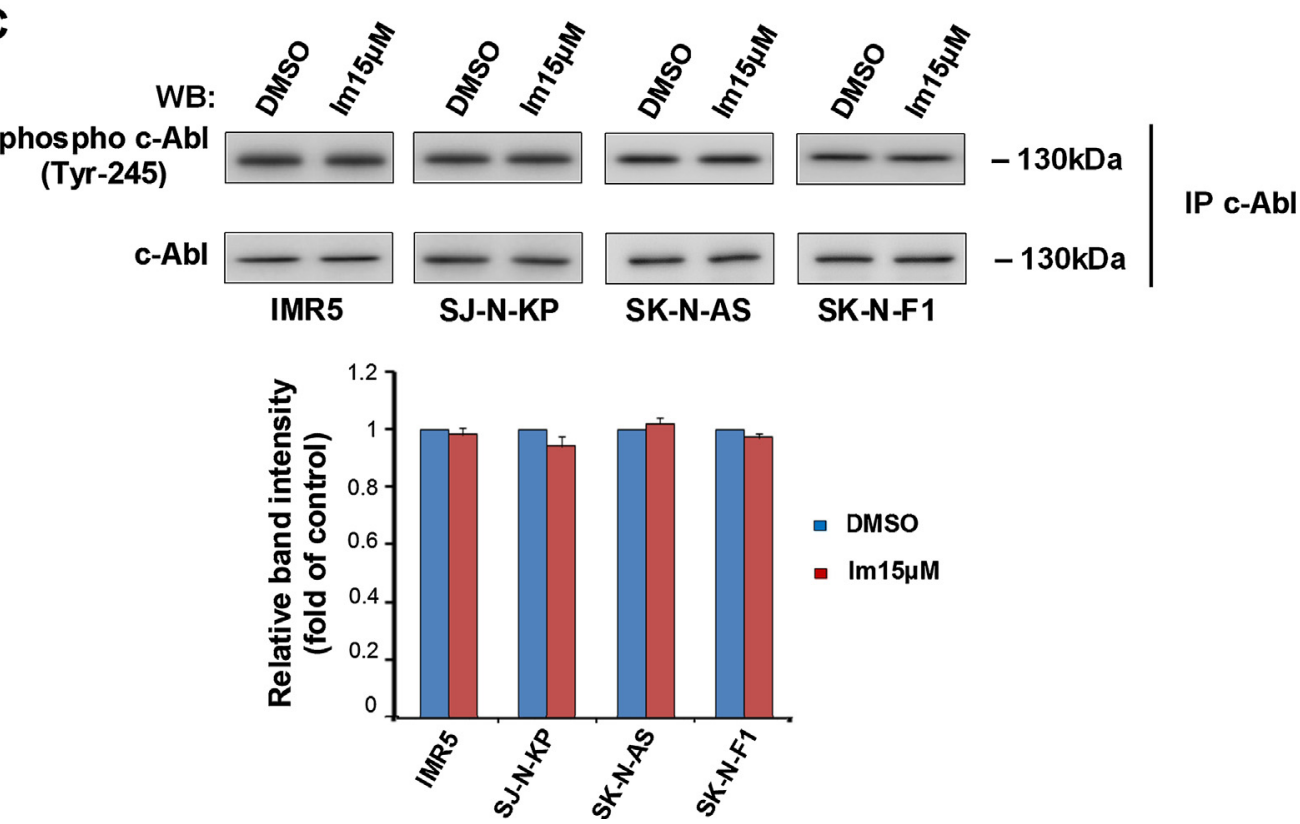

Fig. 8. Evaluation of c-Abl phosphorylation on Tyr-245.

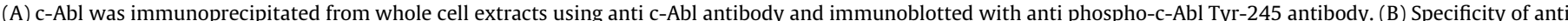

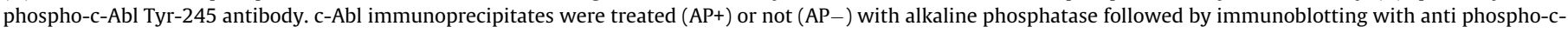

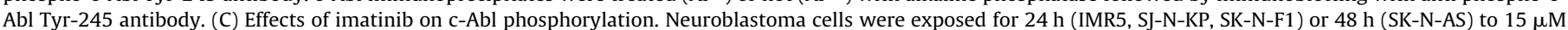

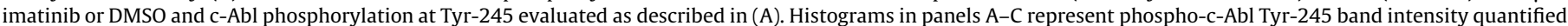

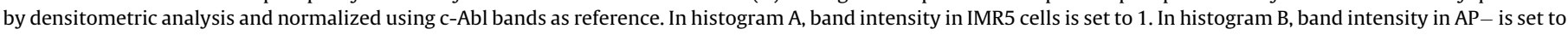

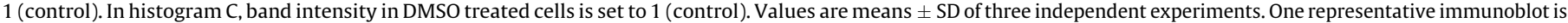
shown. Statistical significance: ${ }^{*} P<0.05,{ }^{* *} P<0.01$ (versus IMR5 cells) $\mathrm{df}=4$; ${ }^{\# \# \#} \mathrm{P}<0.001$ (versus $\mathrm{AP}-$ ) $\mathrm{df}=4$. 

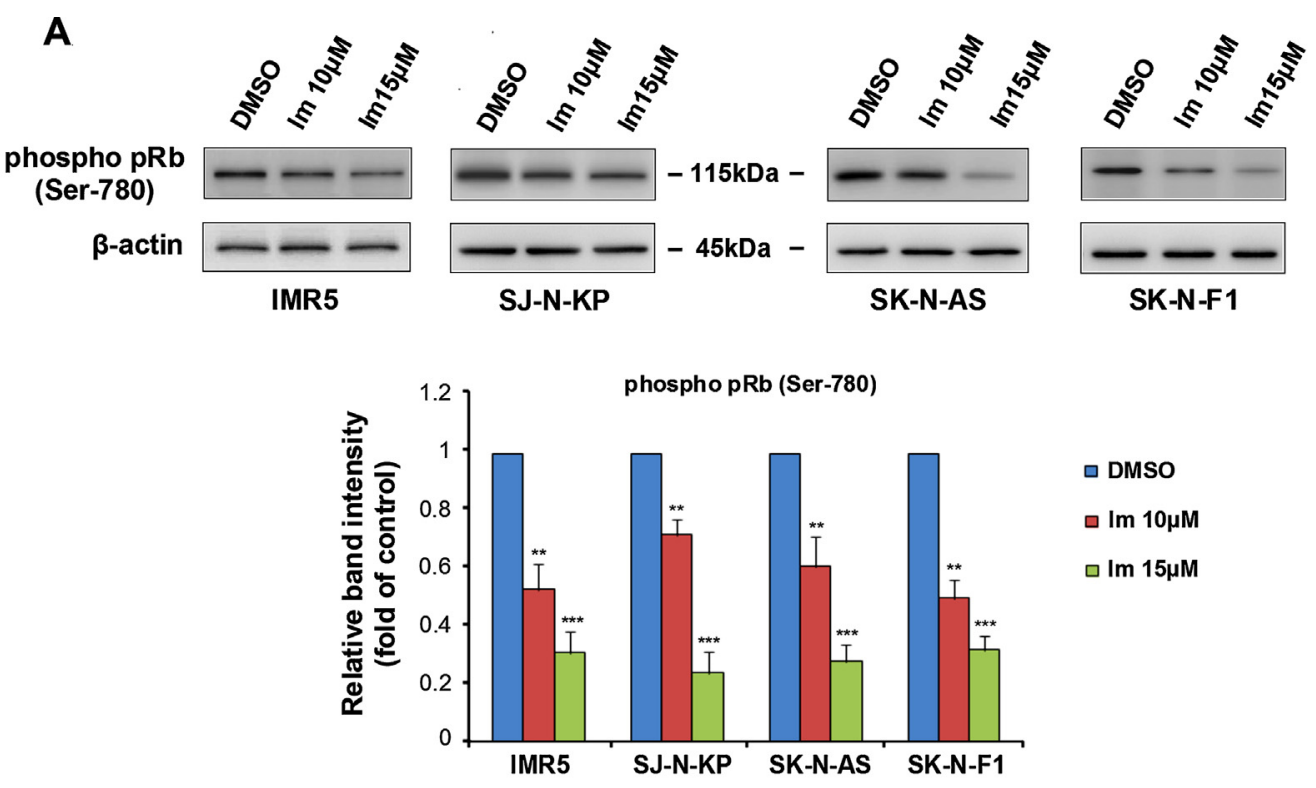

B
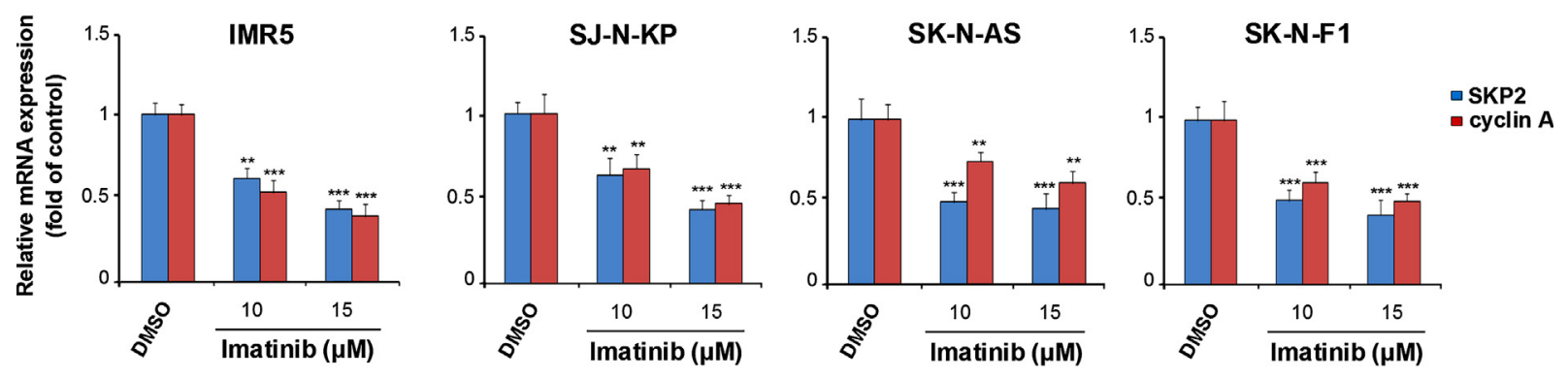

C

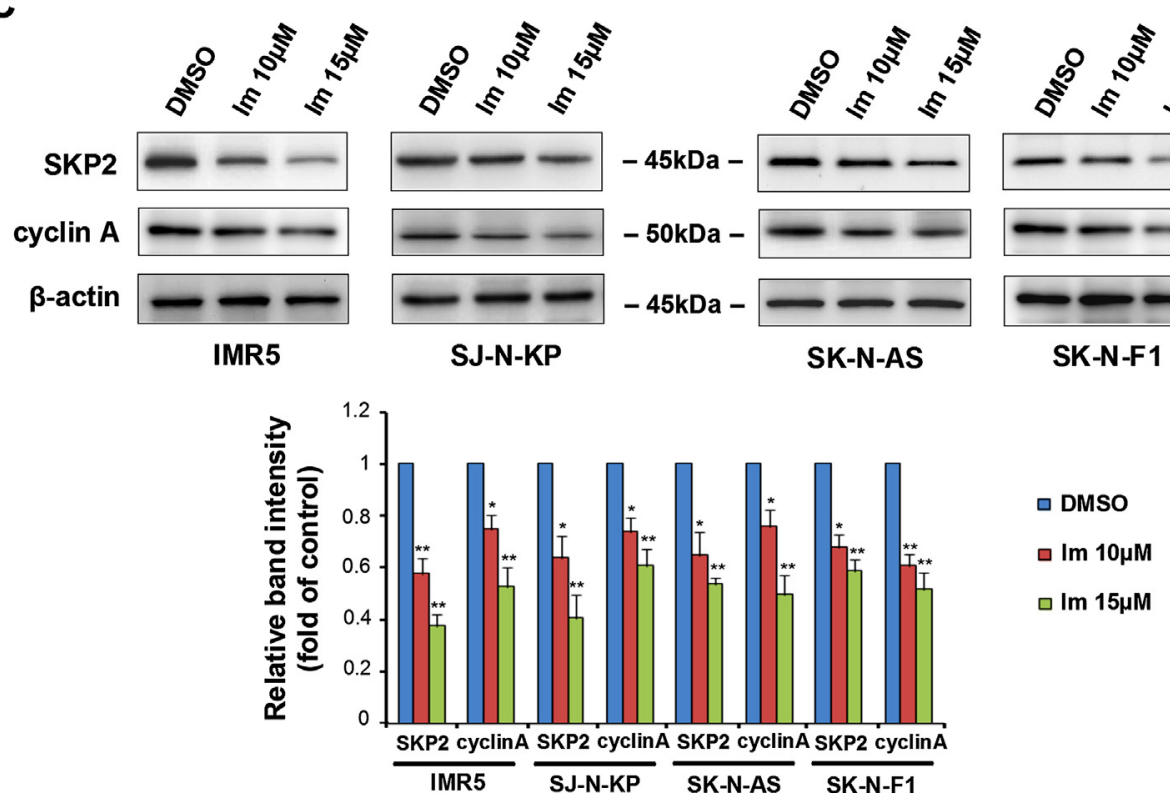

Fig. 9. Effects of imatinib on pRb phosphorylation and SKP2 and cyclin A expression.

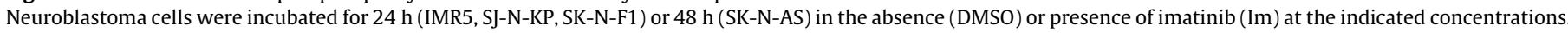

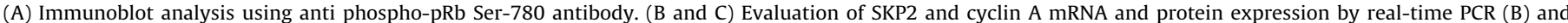

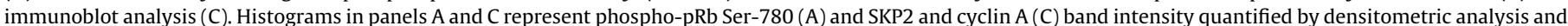

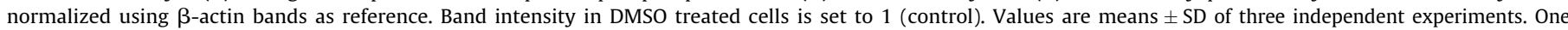

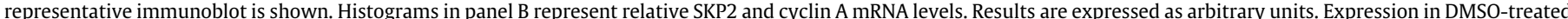

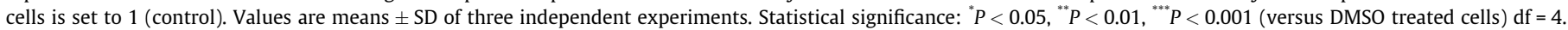


A

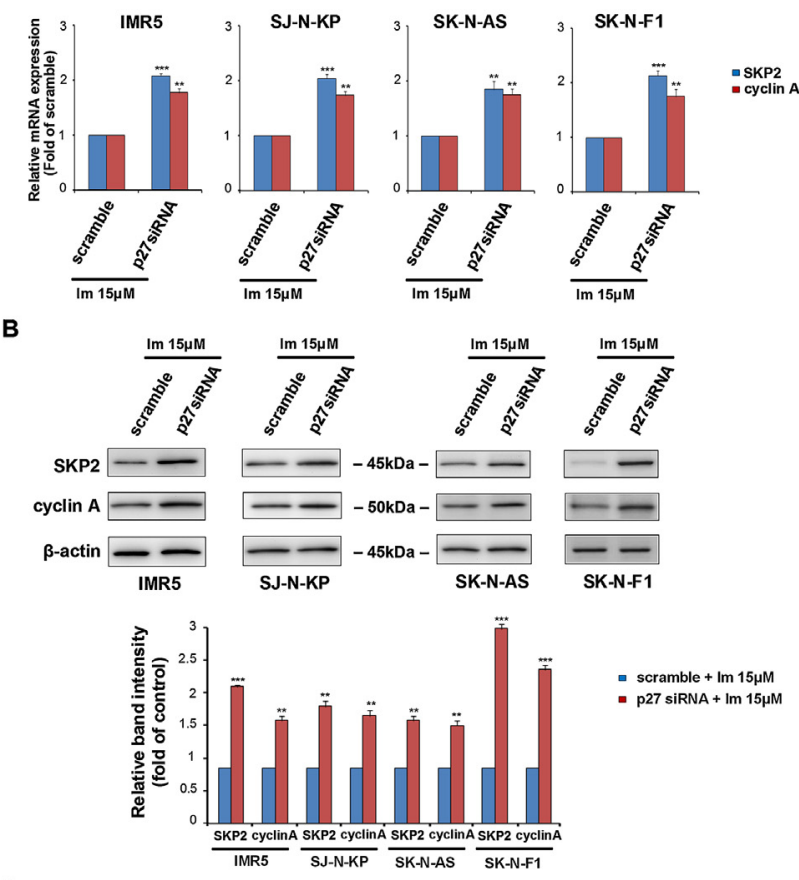

C

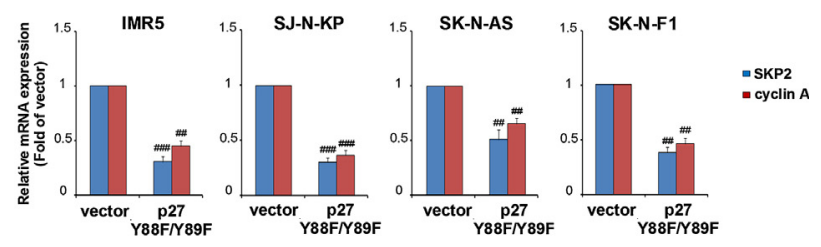

D
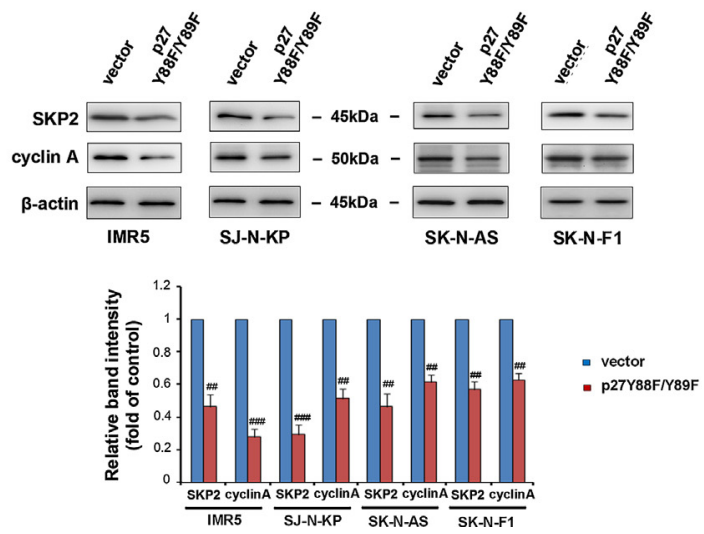

Fig. 10. Effects of silencing of $\mathrm{p} 27^{\mathrm{KIP} 1}$ or expression of $\mathrm{p} 27^{\mathrm{Y} 88 \mathrm{~F} / \mathrm{Y} 89 \mathrm{~F}}$ on E2F target genes.

(A and B) Cells were transfected with $\mathrm{p} 27^{\mathrm{KIP} 1}$-targeting siRNAs or with nontargeting control siRNA (scramble). After $24 \mathrm{~h}$ from transfection, cells were treated with $15 \mu \mathrm{M}$ imatinib for additional $24 \mathrm{~h}$ (SJ-N-KP, IMR5, SK-N-F1) or $48 \mathrm{~h}$ (SK-N-AS) and SKP2 and cyclin A mRNA and protein expression evaluated by real-time PCR (A) and immunoblot analysis (B). Histograms in panel A represent SKP2 and cyclin A relative mRNA levels. Results are expressed as arbitrary units. Expression in scramble is set to 1 (control). Values are means $\pm S D$ of three independent experiments. Histogram in panel B represents SKP2 and cyclin A band intensity quantified by densitometric analysis and normalized using $\beta$-actin bands as reference. Band intensity in scramble is set to 1 (control). Values are means \pm SD of three independent experiments. One representative immunoblot is shown. (C and D) Cells were transfected with a plasmid coding for $\mathrm{p} 27^{\mathrm{Y} 88 \mathrm{~F} / \mathrm{Y} 89 \mathrm{~F}}$ or empty plasmid (vector). After $24 \mathrm{~h}$ from transfection, SKP2 and cyclin A mRNA and protein expression were evaluated by real-time PCR (C) and immunoblot analysis (D). Histograms in panel C represent SKP2 and cyclin A relative mRNA levels. Results are expressed as arbitrary units. Expression in vector is set to 1 (control). Values are means $\pm S D$ of three independent experiments. Histogram in panel D represents SKP2 and cyclin A band intensity quantified by densitometric analysis and normalized using $\beta$-actin bands as
This led us to hypothesize that in imatinib treated cells E2F activity is decreased. To test this hypothesis, the expression of SKP2 and cyclin A, two E2F responsive genes known to be upregulated in neuroblastoma cells $[30,31]$ was evaluated. As shown in Fig. 9B and C, in cells exposed to 10 and $15 \mu \mathrm{M}$ imatinib the expression of SKP2 and cyclin A was decreased at the mRNA and protein levels. Importantly, in cells subjected to $\mathrm{p} 27^{\mathrm{KIP} 1}$ gene silencing the effects of imatinib on the expression of SKP2 and cyclin A were prevented, thus excluding a direct inhibitory effect of imatinib on SKP2 and cyclin A expression (Fig. 10A and B). Expression of $\mathrm{p} 27^{\mathrm{Y} 88 \mathrm{~F} / \mathrm{Y} 8 \mathrm{~F}}$ but not wild type $\mathrm{p} 27^{\mathrm{KIP} 1}$ (not shown) recapitulated the effects of imatinib on SKP2 and cyclin A expression (Fig. 10C and D). Taken together, these data indicate that $\mathrm{p} 27^{\mathrm{KIP} 1}$-dependent downregulation of E2F-controlled cell cycle regulatory genes is an important consequence of the exposure of neuroblastoma cells to imatinib.

Of note, transfection of neuroblastoma cells with a plasmid coding for a constitutively active form of $\mathrm{pRb}$ that lacks all cyclin DCDK docking sites and all but one potential cyclin E-CDK docking sites ( $\mathrm{pRb} \Delta 882$ ) [32], caused the downregulation of SKP2 and cyclin A expression, demonstrating that in neuroblastoma cells SKP2 and cyclin A expression can be repressed by active pRb (Fig. 11).

\section{Discussion}

In the present study we found that exposure of neuroblastoma cell lines to 1-15 $\mu \mathrm{M}$ imatinib resulted in a dose dependent inhibition of BrdU incorporation into newly synthesized DNA. This effect was dependent on the upregulation of the CDK inhibitor $\mathrm{p} 27^{\mathrm{KIP} 1}$ in the nuclear compartment as demonstrated by siRNA-mediated depletion of $\mathrm{p} 27^{\mathrm{KIP} 1}$, which prevented the effects of imatinib on BrdU incorporation. Regulation of $\mathrm{p} 27^{\mathrm{KIP} 1}$ protein levels is mainly achieved by ubiquitin dependent proteolysis [27,33]; however, increased p2 $7^{\mathrm{KIP} 1}$ mRNA levels in imatinib-treated cells have been described [34]. Real-time PCR assays ruled-out increased $\mathrm{p} 27^{\mathrm{KIP} 1}$ mRNA levels in neuroblastoma cells exposed to imatinib. In contrast, cycloheximide chase assays demonstrated a substantial increase in $\mathrm{p} 27^{\mathrm{KIP} 1}$ protein stability. Taken together, these results support the conclusion that $\mathrm{p} 27^{\mathrm{KIP} 1}$ upregulation in the nuclear compartment promoted by increased protein stability mediates the antiproliferative effects of imatinib on neuroblastoma cells. The lower p27 $7^{\mathrm{KIP} 1}$ gene expression in MYCN-amplified IMR5 cells (Fig. 3A) provides an explanation of the apparently less efficient stabilization of $\mathrm{p} 27^{\mathrm{KIP} 1}$ in this cell line (Fig. 3B). Phosphorylation at Thr-187 by cyclin E-CDK2 plays a well established role in the regulation of $\mathrm{p} 27^{\mathrm{KIP} 1}$ protein stability [3]. In addition, phosphorylation on tyrosine residues by Abl- or Src-family non-receptor tyrosine kinases has been demonstrated to prime p2 $7^{\mathrm{KIP} 1}$ for Thr-187 phosphorylation [4]. We provide evidence that in neuroblastoma cells exposed to imatinib, the content of phospho-Thr-187 and phospho-tyrosine in $\mathrm{p} 27^{\mathrm{KIP} 1}$ immunoprecipitates consistently decreased. This result supports a model in which imatinib by inhibiting $\mathrm{p} 27^{\mathrm{KIP} 1}$ tyrosine phosphorylation restores the inhibitory activity of $\mathrm{p} 27^{\mathrm{KIP} 1}$ itself on cyclin E-CDK2 resulting in decreased phosphorylation at Thr-187. To test this hypothesis,

reference. Band intensity in vector is set to 1 (control). Values are means \pm SD of three independent experiments. One representative immunoblot is shown. Statistical significance: ${ }^{* *} P<0.01, \quad{ }^{* * *} P<0.001 \quad$ (versus scramble), $\mathrm{df}=4 ; \quad{ }^{\# \#} P<0.01$, \#\#\# $P<0.001$ (versus vector), $\mathrm{df}=4$.

Comparable results were obtained when cells were transfected with a pool of two p2 $7^{\mathrm{KI} 1}$-targeting siRNAs or when each siRNA was used individually. 
CDK2 was depleted from neuroblastoma cells by siRNAmediated gene silencing, which resulted in the upregulation of endogenous $\mathrm{p} 27^{\mathrm{KIP} 1}$ containing a greatly decreased amount of phosphorylated Thr-187 but an unchanged phosphotyrosine level. These results demonstrate that in proliferating neuroblastoma cells $\mathrm{p} 27^{\mathrm{KIP} 1}$ is constitutively phosphorylated on tyrosine residues and indicate that $\mathrm{p} 27^{\mathrm{KIP} 1}$ phosphorylation on tyrosine residues does not require prior phosphorylation at Thr-187.

Previous studies have demonstrated that overexpression of c-Abl in eukaryotic cells promotes $\mathrm{p} 27^{\mathrm{KIP} 1}$ phosphorylation on tyrosine residues [35] therefore, the potential involvement of c-Abl in p $27^{\mathrm{KIP} 1}$ tyrosine phosphorylation in neuroblastoma cell lines was investigated. To do this, neuroblastoma cells were transfected with siRNAs to c-Abl. Depletion of c-Abl resulted in the upregulation of $\mathrm{p} 27^{\mathrm{KIP} 1}$ in the absence of changes in $\mathrm{p} 27^{\mathrm{KIP} 1}$ mRNA levels. Strikingly, virtually no phosphotyrosine or phosphorylated Thr-187 was detected in p27 ${ }^{\mathrm{KIP} 1}$ immunoprecipitates from cells subjected to c-Abl knockdown, recapitulating the effects of imatinib. Immunoprecipitation experiments provided evidence of the interaction between c-Abl and p $27^{\mathrm{KIP} 1}$, consistent with a direct mechanism of phosphorylation (Fig. 6D). Collectively, these results highlight a previously unknown role for $\mathrm{c}-\mathrm{Abl}$ in the regulation of $\mathrm{p} 27^{\mathrm{KIP} 1}$ stability in vivo and support the conclusion that inhibition of c-Abldependent phosphorylation of $\mathrm{p} 27^{\mathrm{KIP} 1}$ on tyrosine residues is the mechanism of the imatinib-mediated stabilization of $\mathrm{p} 27^{\mathrm{KIP} 1}$ in neuroblastoma cells. To further test the effects of the loss of $\mathrm{p} 27^{\mathrm{KIP} 1}$ phosphorylation on tyrosine residues, neuroblastoma cells were transfected with a plasmid coding for a mutated form of $\mathrm{p} 27^{\mathrm{KIP} 1}\left(\mathrm{p} 27^{\mathrm{Y} 88 \mathrm{~F} / \mathrm{Y} 89 \mathrm{~F}}\right)$ that cannot be phosphorylated on Tyr88 and Tyr-89, the major phospho-acceptor sites of $\mathrm{p} 27^{\mathrm{KIP} 1}$ targeted by c-Abl $[4,5]$. Transfection with $\mathrm{p} 27^{\mathrm{Y} 88 \mathrm{~F} / \mathrm{Y} 89 \mathrm{~F}}$ but not with a plasmid coding for wild type $\mathrm{p} 27^{\mathrm{KIP} 1}$, resulted in the expression of a stable protein which lacked phosphorylated Thr-187. Moreover, expression of $\mathrm{p} 27^{\mathrm{Y} 88 \mathrm{~F} / \mathrm{Y} 89 \mathrm{~F}}$ but not wild type $\mathrm{p} 27^{\mathrm{KIP} 1}$, recapitulated the effects of imatinib on BrdU
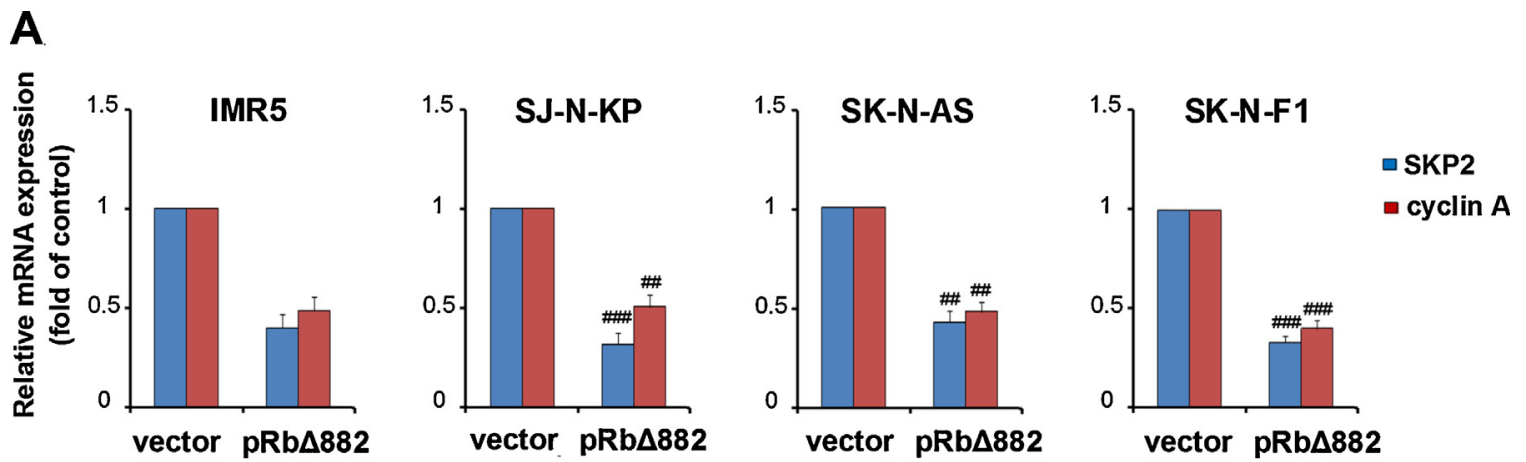

B
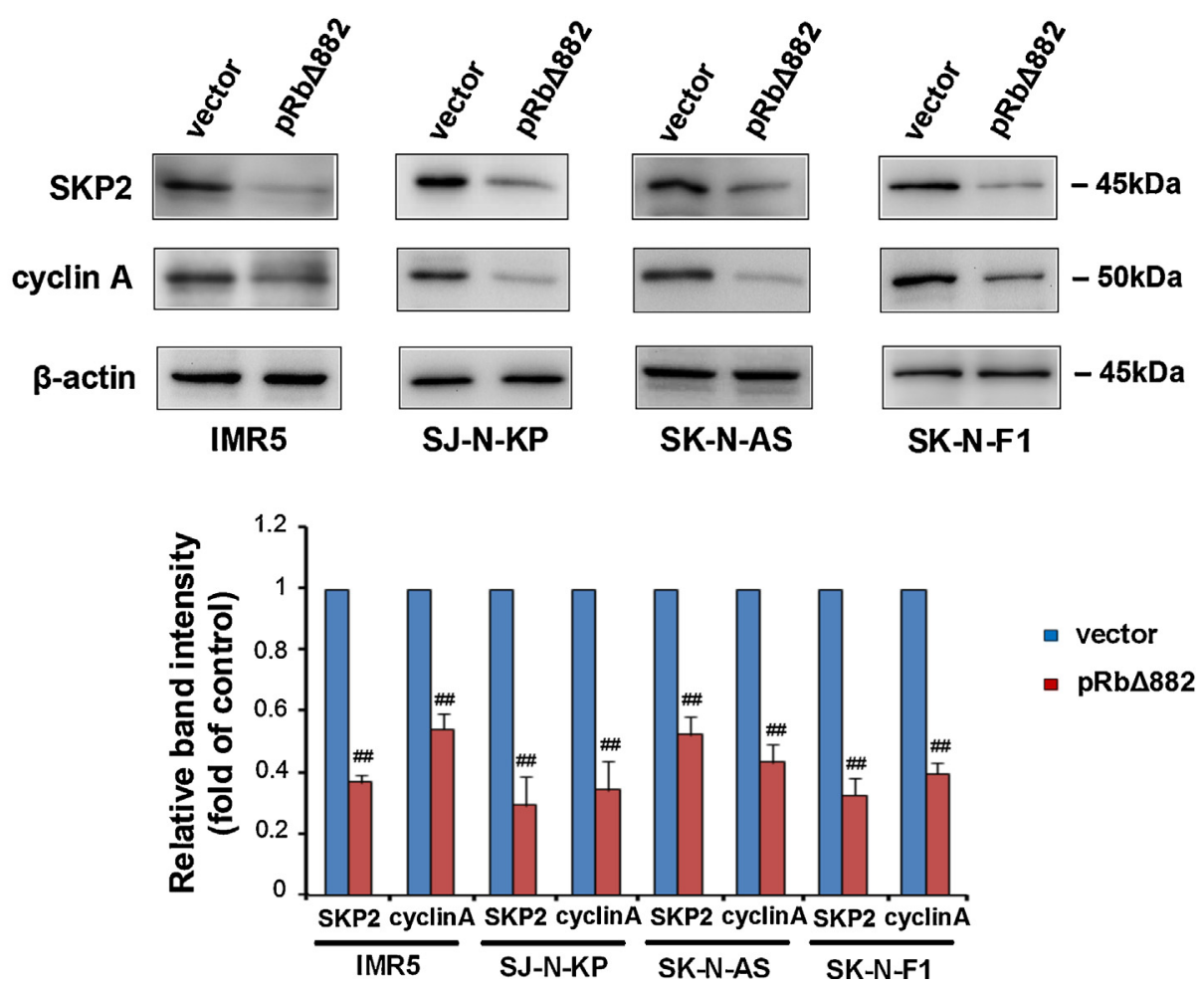

Fig. 11. Effects of the expression of $\mathrm{pRb} \Delta 882$.

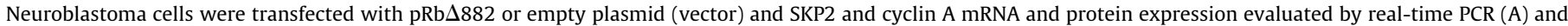

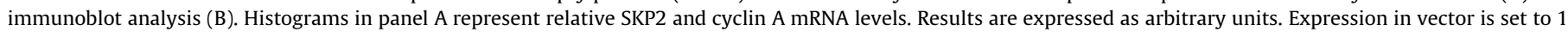

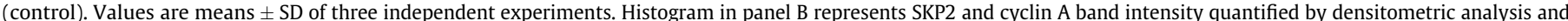

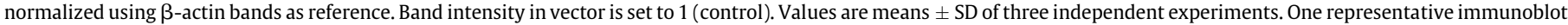
is shown. Statistical significance: ${ }^{\# \#} P<0.01$, ${ }^{\# \# \#} P<0.001$ (versus vector), $\mathrm{df}=4$ 
incorporation and $\mathrm{pRb}$ phosphorylation at the CDK2-specific site Thr-821 (Fig. 7C and D). These results provide further support for the conclusion that in neuroblastoma cells tyrosine phosphorylation negatively regulates the stability and inhibitory activity of $\mathrm{p} 27^{\mathrm{KIP} 1}$. Moreover, these data demonstrate that inhibition of p27 ${ }^{\text {KIP1 }}$ tyrosine phosphorylation exerts growth inhibitory effects on neuroblastoma cells. Tyr-245 is a major site of regulatory control in c-Abl. Phosphorylation on Tyr-245, by disrupting the intra-molecular engagement between the $\mathrm{SH} 3$ domain and the SH2-kinase linker domain of the auto-inhibited structure, stabilizes c-Abl in an open and active conformation [9]. We found that a significant fraction of cellular c-Abl is phosphorylated on Tyr-245, consistent with an open and active conformation of the enzyme. Given the low affinity of phosphorylated c-Abl for imatinib (IC $50 \approx 7 \mu \mathrm{M}$ ) [10,11], this result provides a molecular explanation for the relatively high imatinib concentrations ( $\geq 10 \mu \mathrm{M})$ required to inhibit neuroblastoma cell proliferation, reported in this and other studies [13,36]. Importantly, exposure to imatinib did not affect Tyr-245 phosphorylation, suggesting that an imatinib insensitive tyrosine kinase(s) mediates c-Abl activation in neuroblastoma cells. On the basis of the well established role played by c-Src in the activation of c-Abl mitogenic function [37] and the capacity of Src-family kinases to render c-Abl resistant to imatinib [38], a role for c-Src in c-Abl activation in neuroblastoma cells can be envisaged. Consistent with this hypothesis, increased c-Src activity was detected in neuroblastoma cell lines [39]. Further work is needed to clarify this issue.

In high risk neuroblastoma, deregulated E2F transcriptional activity caused by functional inactivation of the tumor suppressor $\mathrm{pRb}$ results in elevated expression of cell-cycle regulatory proteins, high proliferation rate and aggressive phenotype [40]. Upon mitogenic stimulation $\mathrm{pRb}$ functional inactivation is promoted through sequential phosphorylation by cyclin D-CDK4/6 and cyclin E-CDK2 complexes and results in the release of active E2F1-3 transcription factors capable of inducing the expression of genes encoding proteins crucial for the $\mathrm{G} 1$ to $S$ phase transition $[41,42]$. In neuroblastoma cells cyclin D1 and CDK4 overexpression has been reported to play a role in $\mathrm{pRb}$ inactivation [30]. In this study, we show that in imatinib treated cells pRb phosphorylation at the CDK2-specific Thr-821 and CDK4-specific Ser-780 was decreased and in parallel the expression of two E2F responsive genes previously reported to be upregulated in neuroblastoma cells: SKP2 and cyclin A [30,31] was downregulated. Importantly, silencing of $\mathrm{p} 27^{\mathrm{KIP} 1}$ prevented the imatinib-dependent downregulation of SKP2 and cyclin A whereas expression of $\mathrm{p} 27^{\mathrm{Y} 88 \mathrm{~F} / \mathrm{Y} 89 \mathrm{~F}}$ recapitulated it. Collectively, these data are consistent with the conclusion that downregulation of SKP2 and cyclin A is an important effect of the exposure of neuroblastoma cells to imatinib. Since SKP2 is reported to act as a cofactor of c-MYC transcriptional activity [43], it is tempting to speculate that in imatinib treated cells MYCN transcriptional activity may be downregulated [31].

The expression by neuroblastoma cells of drug efflux transporters of the ABC transporter family such as MDR1 [44] and MRP1 [45] raises the possibility that drug efflux is a major determinant of the reduced sensitivity of neuroblastoma cells to imatinib. However, when evaluating this possibility the following points should be considered. First, imatinib is not a substrate for MRP1 [46] which in clinical settings [45] and in animal models [47] has been demonstrated to be a key factor for multidrug resistance in neuroblastoma. Second, although imatinib is a substrate of MDR1, the reported $\mathrm{IC}_{50}$ of imatinib for MDR1 (3-8 $\mu \mathrm{M})$ [48] is $1-2 \log$ greater than the $\mathrm{IC}_{50}$ of imatinib for its high affinity targets. Third, while a previous study demonstrated that MDR1 expression is considerably greater in

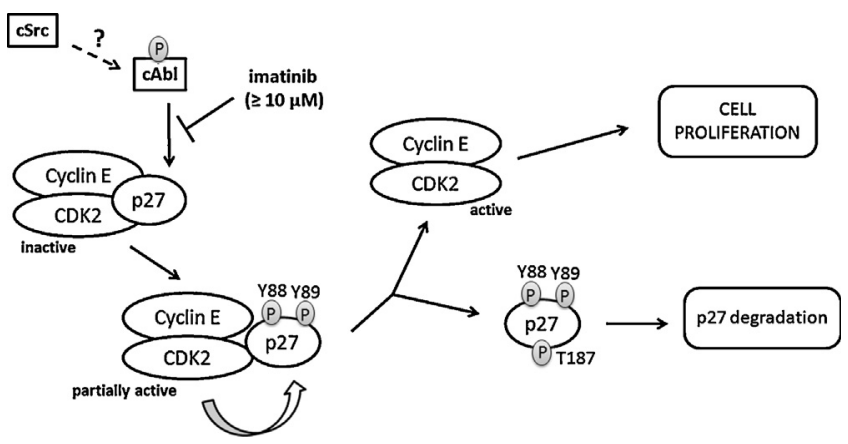

Fig. 12. Model of the proposed mechanism of $\mathrm{p} 27^{\mathrm{KIP} 1}$ inactivation in neuroblastoma cells.

Active c-Abl phosphorylates $\mathrm{p} 27^{\mathrm{KIP} 1}$ at tyrosine residues 88 and 89 resulting in CDK2 partial activation. Following CDK2-dependent phosphorylation on Thr-187, $\mathrm{p} 27^{\mathrm{KIP} 1}$ is degraded by the $26 \mathrm{~S}$ proteasome and full CDK2 activation ensues.

SK-N-F1 cells than in SK-N-AS cells [49], the inhibition of BrdU incorporation exerted by imatinib in the two cell lines was comparable (Fig. 1A). For these reasons and because of the relatively high imatinib concentration necessary to inhibit active c-Abl $[10,11]$, a major role for drug efflux transporters in the resistance of neuroblastoma cells to imatinib shown in this study seems unlikely. The longer exposure time to imatinib ( $48 \mathrm{~h}$ instead of $24 \mathrm{~h}$ ) necessary to inhibit BrdU incorporation in SK-NAS cells to an extent comparable with that of the other cell lines could be explained by the greater amount of Tyr-245 phosphorylated c-Abl detected in these cells (Fig. 8A). However, a reduced expression or activity of the OCT1 transporter which mediates imatinib influx [50] could also explain this result.

In conclusion, in this study we demonstrated that in neuroblastoma cells active c-Abl constitutively phosphorylates $\mathrm{p} 27^{\mathrm{KIP} 1}$ on tyrosine residues, promoting $\mathrm{p} 27^{\mathrm{KIP} 1}$ downregulation and uncontrolled cell proliferation (Fig. 12). Moreover, we provided evidence that the mechanism of the antiproliferative effect of imatinib on neuroblastoma cells relies on the inhibition of p $27^{\mathrm{KIP} 1}$ tyrosine phosphorylation by active c-Abl. The collaborative interaction between c-Abl and CDK2 in controlling p2 $27^{\mathrm{KIP} 1}$ stability, suggests a potential synergistic interaction between imatinib and CDK2 inhibitors in inhibiting neuroblastoma cell proliferation. Should this be the case, new treatments for the control of minimal residual disease could be developed. Further work is needed to test this hypothesis.

\section{Conflict of interest}

The authors disclose no potential conflicts of interest.

\section{Acknowledgments}

This study was funded by Progetti di ricerca finanziati dall'Università' degli Studi di Torino and Regione Piemonte, Ricerca Scientifica Applicata project A189 and by the TAKTIC consortium FP7-SME-2012-315746-TAKTIC.

\section{References}

[1] Chu IM, Hengst L, Slingerland JM. The Cdk inhibitor p27 in human cancer: prognostic potential and relevance to anticancer therapy. Nat Rev Cancer 2008;8:253-67.

[2] Lee J, Kim SS. The function of p27 KIP1 during tumor development. Exp Mol Med 2009;41:765-71.

[3] Bloom J, Pagano M. Deregulated degradation of the cdk inhibitor p27 and malignant transformation. Semin Cancer Biol 2003;13:41-7.

[4] Grimmler M, Wang Y, Mund T, Cilensek Z, Keidel EM, Waddell MB, et al. Cdkinhibitory activity and stability of p27Kip 1 are directly regulated by oncogenic tyrosine kinases. Cell 2007;128:269-80. 
[5] James MK, Ray A, Leznova D, Blain SW. Differential modification of p27Kip1 controls its cyclin D-cdk4 inhibitory activity. Mol Cell Biol 2008;28:498-510.

[6] Russo AA, Jeffrey PD, Patten AK, Massague J, Pavletich NP. Crystal structure of the p27Kip1 cyclin-dependent-kinase inhibitor bound to the cyclin A-Cdk2 complex. Nature 1996;382:325-31.

[7] Brasher BB, Van Etten RA. c-Abl has high intrinsic tyrosine kinase activity that is stimulated by mutation of the Src homology 3 domain and by autophosphorylation at two distinct regulatory tyrosines. J Biol Chem 2000;275: 35631-37.

[8] Nagar B, Hantschel O, Young MA, Scheffzek K, Veach D, Bornmann W, et al. Structural basis for the autoinhibition of c-Abl tyrosine kinase. Cell 2003;112:859-71.

[9] Hantschel O, Superti-Furga G. Regulation of the c-Abl and Bcr-Abl tyrosine kinases. Nat Rev Mol Cell Biol 2004;5:33-44.

[10] Nagar B, Bornmann WG, Pellicena P, Schindler T, Veach DR, Miller WT, et al. Crystal structures of the kinase domain of c-Abl in complex with the small molecule inhibitors PD173955 and imatinib (STI-571). Cancer Res 2002;62: 4236-43.

[11] Schindler T, Bornmann W, Pellicena P, Miller WT, Clarkson B, Kuriyan J. Structural mechanism for STI-571 inhibition of abelson tyrosine kinase. Science 2000;289:1938-42.

[12] Deininger M, Buchdunger E, Druker BJ. The development of imatinib as a therapeutic agent for chronic myeloid leukemia. Blood 2005;105:2640-53.

[13] Vitali R, Cesi V, Nicotra MR, McDowell HP, Donfrancesco A, Mannarino O, et al. c-Kit is preferentially expressed in MYCN-amplified neuroblastoma and its effect on cell proliferation is inhibited in vitro by STI-571. Int J Cancer 2003; 106:147-52

[14] Meco D, Riccardi A, Servidei T, Brueggen J, Gessi M, Riccardi R, et al. Antitumor activity of imatinib mesylate in neuroblastoma xenografts. Cancer Let 2005;228:211-9.

[15] Fischer M, Berthold F. Characterization of the gene expression profile of neuroblastoma cell line IMR-5 using serial analysis of gene expression. Cancer Lett 2003;190:79-87.

[16] Tonelli R, Purgato S, Camerin C, Fronza R, Bologna F, Alboresi S, et al. Anti-gene peptide nucleic acid specifically inhibits MYCN expression in human neuroblastoma cells leading to cell growth inhibition and apoptosis. Mol Cancer Ther 2005;4:779-86.

[17] Thompson PM, Maris JM, Hogarty MD, Seeger RC, Reynolds CP, Brodeur GM, et al. Homozygous deletion of CDKN2A (p16INK4a/p14ARF) but not within 1 p36 or at other tumor suppressor loci in neuroblastoma. Cancer Res 2001;61: $679-86$.

[18] De Brouwer S, De Preter K, Kumps C, Zabrocki P, Porcu M, Westerhout EM, et al. Meta-analysis of neuroblastomas reveals a skewed ALK mutation spectrum in tumors with MYCN amplification. Clin Cancer Res 2010;16:4353-62.

[19] George RE, Sanda T, Hanna M, Frohling S, Luther 2nd W, Zhang J, et al. Activating mutations in ALK provide a therapeutic target in neuroblastoma. Nature 2008;455:975-8

[20] Tonini GP, Casalaro A, Cara A, Di Martino D. Inducible expression of calcyclin, a gene with strong homology to S-100 protein, during neuroblastoma cell differentiation and its prevalent expression in Schwann-like cell lines. Cancer Res 1991:51:1733-7.

[21] Voigt A, Zintl F. Effects of retinoic acid on proliferation, apoptosis, cytotoxicity, migration, and invasion of neuroblastoma cells. Med Pediatr Oncol 2003;40: 205-13.

[22] Bian X, Giordano TD, Lin HJ, Solomon G, Castle VP, Opipari Jr AW. Chemotherapy-induced apoptosis of S-type neuroblastoma cells requires caspase- 9 and is augmented by CD95/Fas stimulation. J Biol Chem 2004;279:4663-9.

[23] Buschbeck M, Hofbauer S, Di Croce L, Keri G, Ullrich A. Abl-kinase-sensitive levels of ERK5 and its intrinsic basal activity contribute to leukaemia cell survival. EMBO Rep 2005;6:63-9.

[24] Lupino E, Ramondetti C, Piccinini M. IkappaB kinase beta is required for activation of NF-kappaB and AP-1 in CD3/CD28-stimulated primary CD4(+) T cells. J Immunol 2012;188:2545-55.

[25] Cheng B, Maffi SK, Martinez AA, Acosta YP, Morales LD, Roberts JL. Insulin-like growth factor-I mediates neuroprotection in proteasome inhibition-induced cytotoxicity in SH-SY5Y cells. Mol Cell Neurosci 2011;47:181-90.

[26] Sherr CJ, Roberts JM. CDK inhibitors: positive and negative regulators of G1phase progression. Genes Dev 1999;13:1501-12.

[27] Carrano AC, Eytan E, Hershko A, Pagano M. SKP2 is required for ubiquitinmediated degradation of the CDK inhibitor p27. Nat Cell Biol 1999;1: 193-9.
[28] Chu I, Sun J, Arnaout A, Kahn H, Hanna W, Narod S, et al. p27 phosphorylation by Src regulates inhibition of cyclin E-Cdk2. Cell 2007;128:281-94.

[29] Molenaar JJ, Ebus ME, Geerts D, Koster J, Lamers F, Valentijn LJ, et al. Inactivation of CDK2 is synthetically lethal to MYCN over-expressing cancer cells. Proc Natl Acad Sci U S A 2009;106:12968-73.

[30] Molenaar JJ, Ebus ME, Koster J, van Sluis P, van Noesel CJ, Versteeg R, et al. Cyclin D1 and CDK4 activity contribute to the undifferentiated phenotype in neuroblastoma. Cancer Res 2008;68:2599-609.

[31] Westermann F, Henrich KO, Wei JS, Lutz W, Fischer M, Konig R, et al. High Skp2 expression characterizes high-risk neuroblastomas independent of MYCN status. Clin Cancer Res 2007;13:4695-703.

[32] Harbour JW, Luo RX, Dei Santi A, Postigo AA, Dean DC. Cdk phosphorylation triggers sequential intramolecular interactions that progressively block $\mathrm{Rb}$ functions as cells move through G1. Cell 1999;98:859-69.

[33] Pagano M, Tam SW, Theodoras AM, Beer-Romero P, Del Sal G, Chau V, et al. Role of the ubiquitin-proteasome pathway in regulating abundance of the cyclin-dependent kinase inhibitor p27. Science 1995;269:682-5.

[34] Andreu EJ, Lledo E, Poch E, Ivorra C, Albero MP, Martinez-Climent JA, et al. BCR$\mathrm{ABL}$ induces the expression of Skp2 through the PI3K pathway to promote p27Kip1 degradation and proliferation of chronic myelogenous leukemia cells. Cancer Res 2005;65:3264-72.

[35] Kardinal C, Dangers M, Kardinal A, Koch A, Brandt DT, Tamura T, et al. Tyrosine phosphorylation modulates binding preference to cyclin-dependent kinases and subcellular localization of p27Kip1 in the acute promyelocytic leukemia cell line NB4. Blood 2006;107:1133-40.

[36] Beppu K, Jaboine J, Merchant MS, Mackall CL, Thiele CJ. Effect of imatinib mesylate on neuroblastoma tumorigenesis and vascular endothelial growth factor expression. J Natl Cancer Inst 2004;96:46-55.

[37] Furstoss O, Dorey K, Simon V, Barila D, Superti-Furga G. Roche S. c-Abl is an effector of Src for growth factor-induced c-myc expression and DNA synthesis. Embo J 2002;21:514-24.

[38] Tanis KQ, Veach D, Duewel HS, Bornmann WG, Koleske AJ. Two distinct phosphorylation pathways have additive effects on Abl family kinase activation. Mol Cell Biol 2003;23:3884-96.

[39] Bolen JB, Rosen N, Israel MA. Increased pp60c-src tyrosyl kinase activity in human neuroblastomas is associated with amino-terminal tyrosine phosphorylation of the src gene product. Proc Natl Acad Sci U S A 1985;82:7275-9.

[40] Hernando E, Nahle Z, Juan G, Diaz-Rodriguez E, Alaminos M, Hemann M, et al. $\mathrm{Rb}$ inactivation promotes genomic instability by uncoupling cell cycle progression from mitotic control. Nature 2004;430:797-802.

[41] Weinberg RA. The retinoblastoma protein and cell cycle control. Cell 1995;81:323-30.

[42] Lundberg AS, Weinberg RA. Functional inactivation of the retinoblastoma protein requires sequential modification by at least two distinct cyclin-cdk complexes. Mol Cell Biol 1998;18:753-61.

[43] von der Lehr N, Johansson S, Wu S, Bahram F, Castell A, Cetinkaya C, et al. The Fbox protein Skp2 participates in c-Myc proteosomal degradation and acts as a cofactor for c-Myc-regulated transcription. Mol Cell 2003;11:1189-200.

[44] Flahaut M, Meier R, Coulon A, Nardou KA, Niggli FK, Martinet D, et al. The Wnt receptor FZD1 mediates chemoresistance in neuroblastoma through activation of the Wnt/beta-catenin pathway. Oncogene 2009;28:2245-56.

[45] Haber M, Smith J, Bordow SB, Flemming C, Cohn SL, London WB, et al Association of high-level MRP1 expression with poor clinical outcome in a large prospective study of primary neuroblastoma. J Clin Oncol 2006;24: 1546-53.

[46] Mukai M, Che XF, Furukawa T, Sumizawa T, Aoki S, Ren XQ, et al. Reversal of the resistance to STI571 in human chronic myelogenous leukemia K562 cells Cancer Sci 2003:94:557-63.

[47] Burkhart CA, Watt F, Murray J, Pajic M, Prokvolit A, Xue C, et al. Small-molecule multidrug resistance-associated protein 1 inhibitor reversan increases the therapeutic index of chemotherapy in mouse models of neuroblastoma. Cancer Res 2009;69:6573-80.

[48] Hegedus T, Orfi L, Seprodi A, Varadi A, Sarkadi B, Keri G. Interaction of tyrosine kinase inhibitors with the human multidrug transporter proteins, MDR1 and MRP1. Biochim Biophys Acta 2002;1587:318-25.

[49] Dijkhuis AJ, Douwes J, Kamps W, Sietsma H, Kok JW. Differential expression of sphingolipids in P-glycoprotein or multidrug resistance-related protein 1 expressing human neuroblastoma cell lines. FEBS Lett 2003;548:28-32.

[50] Milojkovic D, Apperley J. Mechanisms of resistance to imatinib and secondgeneration tyrosine inhibitors in chronic myeloid leukemia. Clin Cancer Res 2009; 15:7519-27. 